Prepared in cooperation with the Miami-Dade Water and Sewer Department

\title{
Seismic-Sequence Stratigraphy and Geologic Structure of the Floridan Aquifer System Near "Boulder Zone" Deep Wells in Miami-Dade County, Florida
}

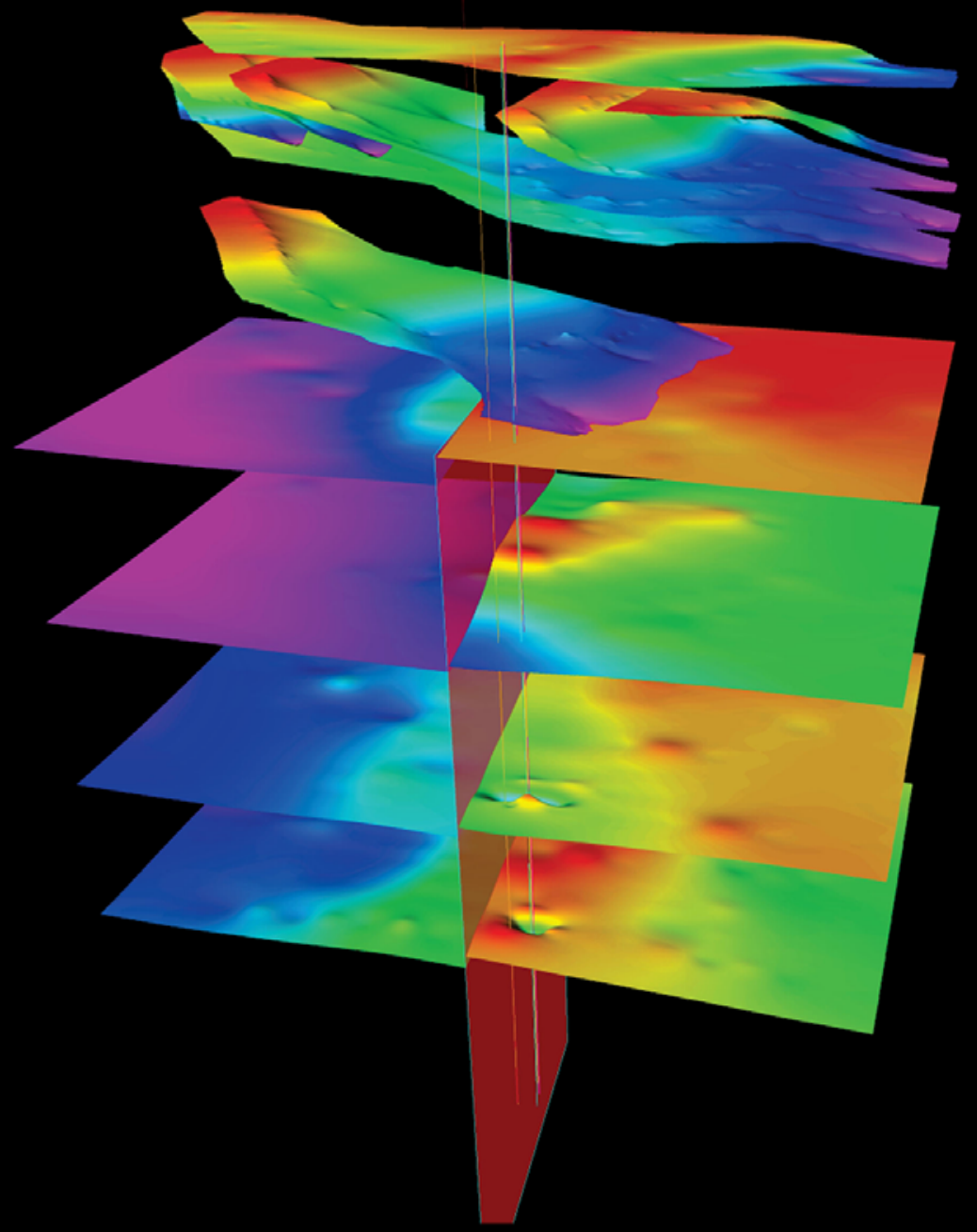

Scientific Investigations Report 2015-5013 
Cover. Image is a three-dimensional diagram showing a geomodel of the Miami-Dade County North District "Boulder Zone" Well Field and surrounding area. (See figure 10 for more information.) 


\section{Seismic-Sequence Stratigraphy and Geologic Structure of the Floridan Aquifer System Near "Boulder Zone" Deep Wells in Miami-Dade County, Florida}

By Kevin J. Cunningham

Prepared in cooperation with the Miami-Dade Water and Sewer Department

Scientific Investigations Report 2015-5013 


\title{
U.S. Department of the Interior SALLY JEWELL, Secretary
}

\section{U.S. Geological Survey \\ Suzette M. Kimball, Acting Director}

\author{
U.S. Geological Survey, Reston, Virginia: 2015
}

For more information on the USGS - the Federal source for science about the Earth, its natural and living resources, natural hazards, and the environment—visit http://www.usgs.gov or call 1-888-ASK-USGS.

For an overview of USGS information products, including maps, imagery, and publications, visit http://www.usgs.gov/pubprod/.

Any use of trade, firm, or product names is for descriptive purposes only and does not imply endorsement by the U.S. Government.

Although this information product, for the most part, is in the public domain, it also may contain copyrighted materials as noted in the text. Permission to reproduce copyrighted items must be secured from the copyright owner.

Suggested citation:

Cunningham, K.J., 2015, Seismic-sequence stratigraphy and geologic structure of the Floridan aquifer system near "Boulder Zone" deep wells in Miami-Dade County, Florida: U.S. Geological Survey Scientific Investigations Report 2015-5013, 28 p., http://dx.doi.org/10.3133/sir20155013.

ISSN 2328-0328 (online) 


\section{Acknowledgments}

Cameron Walker and William J. Streidl, Walker Marine Geophysical Company, provided expert seismic-reflection data acquisition. Virginia Walsh, Miami-Dade Water and Sewer Department, granted access to Miami-Dade North and South District "Boulder Zone" Well Fields. Jeff N. King, USGS, provided very useful technical discussions. Richard L. Westcott, USGS, contributed to interpretation of borehole videos, assistance with geophysical well log display, and construction of a geomodel. 



\section{Contents}

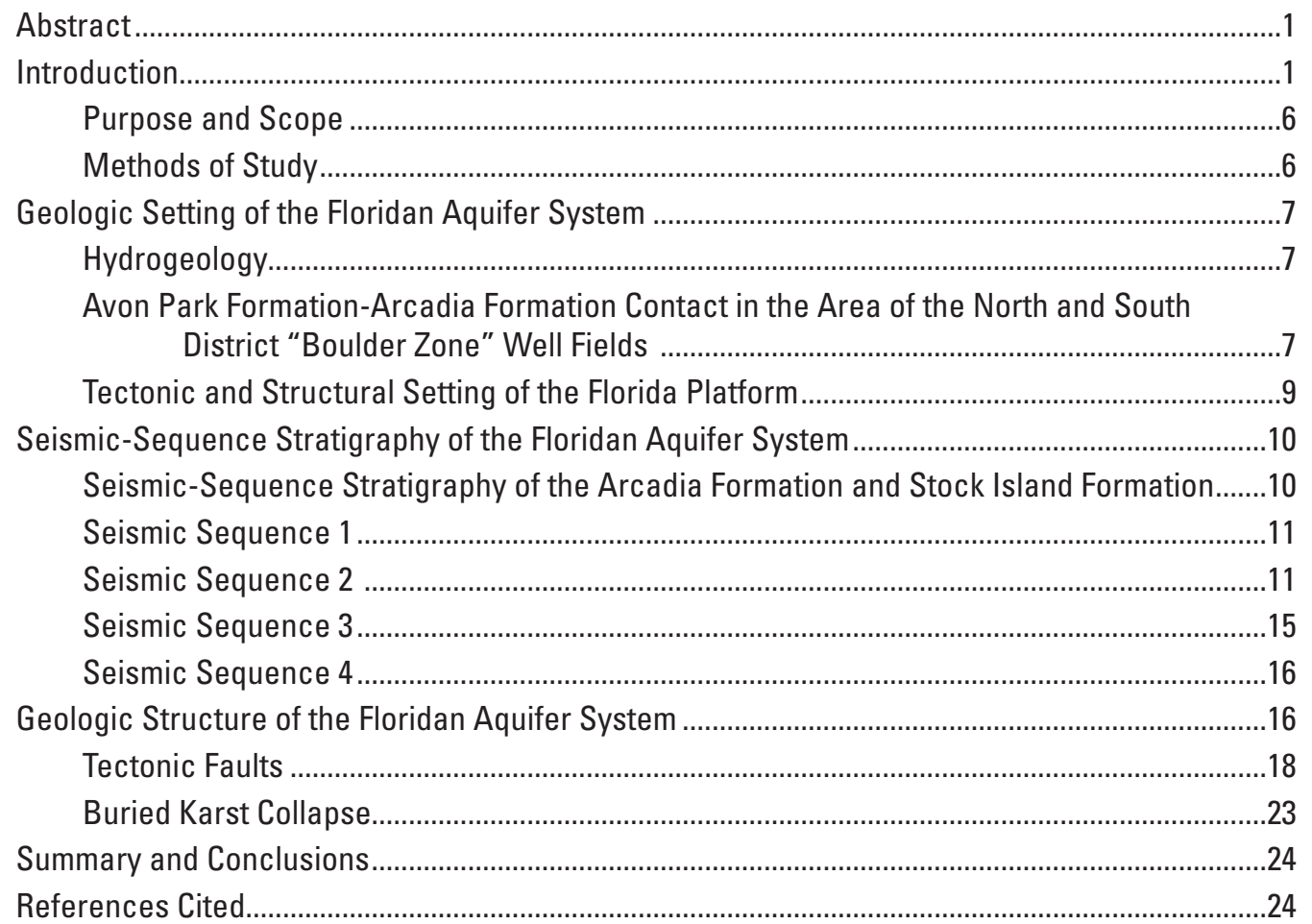

\section{Plates}

[Available at http://pubs.usgs.gov/sir/2015/5013/]

1 Seismic-reflection sections $A-A^{\prime}, B-B^{\prime}$, and $C-C^{\prime}$ with correlations between synthetic seismograms, borehole geophysical data, and seismic-reflection profiles from the North and South District "Boulder Zone" Well Fields, Miami-Dade County, Florida

2 Hydrologic, lithostratigraphic, seismic sequence, and depositional sequence section through North District "Boulder Zone" Well Field, Miami-Dade County, Florida

\section{Figures}

1. Map showing location of Miami-Dade County, Florida, and the study areas that include the North and South District "Boulder Zone" deep-well areas

2. Map showing location of the North District "Boulder Zone" deep-well area, where "Boulder Zone" deep wells MD-IW-1N through MD-IW-4N are located and the location of seismic-reflection survey profiles used in this study area

3. Map showing the location of the South District "Boulder Zone" deep-well area, where "Boulder Zone" deep wells MD-IW-1S through MD-IW-17S and BZ-1 are located and the location of seismic-reflection survey profiles used in this study area 
4. Correlation chart showing relations between hydrogeologic units, geologic units, and seismic-stratigraphic units

5. Map of conceptualized paleogeography about 140 Mya depicting a fully assembled Florida basement.

6. Seismic-reflection profile examples of seismic sequences 1-4, which combine to span the lower part of the intermediate confining unit and Floridan aquifer system excluding the part below the Boulder Zone.....

7. Seismic-reflection profile N5-pt3 from Biscayne Bay showing a broad sag in seismic reflections interpreted as a collapse structure within the middle Eocene carbonate strata of the Floridan aquifer system.

8. Seismic-reflection profile EW7 acquired in Biscayne Bay showing downlapping seismic reflections along the top of seismic sequence 1 and onlapping seismic reflections along the tops of seismic sequence 2 and seismic sequence 3

9. Part of seismic reflection profile 2TIE showing inverted V-shaped stacked seismic-reflection configurations within seismic sequence 2 , indicative of a narrow karst collapse structure .

10. Three-dimensional diagram showing geomodel of the Miami-Dade North District "Boulder Zone" Well Field and surrounding area constructed from well-log data and seismic-reflection profiles

11. Seismic-reflection profile N1 from Biscayne Bay showing a nearly vertical strike-slip fault.

12. Seismic-reflection profile C2-HFE2 showing a near-vertical strike-slip fault and a narrow karst collapse structure west of the fault

13. Three-dimensional diagram of geomodel based on 20 seismic-reflection profiles, including the 2TIE seismic-reflection profile.

14. Part of seismic-reflection profile 2TIE showing tectonic compressional anticlinal uplift, truncated seismic-reflection terminations at the upper bounding sequence boundary of the lower Arcadia formation, and downlapping reflections assigned to upper Pliocene or lower Pleistocene sediments 


\section{Conversion Factors}

\begin{tabular}{lll}
\hline \multicolumn{1}{c}{ Multiply } & By & \multicolumn{1}{c}{ To obtain } \\
\hline foot $(\mathrm{ft})$ & \multicolumn{2}{c}{ Length } \\
mile $(\mathrm{mi})$ & 0.3048 & meter $(\mathrm{m})$ \\
\hline \multicolumn{2}{c}{ Velocity } & kilometer $(\mathrm{km})$ \\
\hline mile per hour $(\mathrm{mi} / \mathrm{h})$ & 1.609 & kilometer per hour $(\mathrm{km} / \mathrm{h})$ \\
\hline
\end{tabular}

\section{Datum}

Horizontal coordinate information is referenced to the North American Datum of 1983 (NAD 83).

Altitude, as used in this report, refers to distance above or below sea level.

\section{Supplemental Information}

Concentrations of chemical constituents in water are given in milligrams per liter (mg/L)

\section{Abbreviations}

$\begin{array}{ll}\text { bls } & \text { below land surface } \\ \text { ms } & \text { millisecond } \\ \text { MDWASD } & \text { Miami-Dade Water and Sewer Department } \\ \text { NDBZWF } & \text { North District "Boulder Zone" Well Field } \\ \text { s } & \text { second } \\ \text { SDBZWF } & \text { South District "Boulder Zone" Well Field } \\ \text { USDW } & \text { underground source of drinking water } \\ \text { USGS } & \text { U.S. Geological Survey }\end{array}$





\section{Seismic-Sequence Stratigraphy and Geologic Structure of the Floridan Aquifer System Near "Boulder Zone" Deep Wells in Miami-Dade County, Florida}

By Kevin J. Cunningham

\section{Abstract}

The U.S. Geological Survey, in cooperation with the Miami-Dade Water and Sewer Department, acquired, processed, and interpreted seismic-reflection data near the North and South District "Boulder Zone" Well Fields to determine if geologic factors may contribute to the upward migration of injected effluent into that upper part of the Floridan aquifer system designated by the U.S. Environmental Protection Agency as an underground source of drinking water. The depth of the Boulder Zone at the North and South District "Boulder Zone" Well Fields ranges from about 2,750 to 3,300 feet below land surface (ft bls), whereas overlying permeable zones used as alternative drinking water supply range in depth from about 825 to $1,580 \mathrm{ft}$ bls at the North and South District "Boulder Zone" Well Fields. Seismic-sequence stratigraphy and geologic structures imaged on seismicreflection profiles created for the study describe the part of the Floridan aquifer system overlying and within the Boulder Zone. Features of the Floridan aquifer system underlying the Boulder Zone were not studied because seismic-reflection profiles acquired near the North and South District "Boulder Zone" Well Fields lacked adequate resolution at such depths.

Stratigraphic analysis of seismic-reflection data collected from the study area was mainly applied to the Floridan aquifer system and used to identify four provisional seismic sequences, which extend vertically from near the base of the Floridan aquifer system upward to the lower part of the intermediate confining unit. These four seismic sequences compose a framework in which each sequence includes a major permeable unit of the Floridan aquifer system; from shallowest to deepest, these units are the Upper Floridan aquifer, Avon Park permeable zone, uppermost major permeable zone of the Lower Floridan aquifer, and Boulder Zone. The relations between seismic-sequence stratigraphy and hydrostratigraphy allow for detailed mapping of permeable zones and semiconfining units of the Floridan aquifer system at a level of resolution never before accomplished using well data alone.
In addition to the preceding seismic-reflection analysis, interpretation of geophysical well log data from four effluent injection wells at the North District "Boulder Zone" Well Field delineated a narrow karst collapse structure beneath the injection facility that extends upward about $900 \mathrm{ft}$ from the top of the Boulder Zone to about $125 \mathrm{ft}$ above the top of the uppermost major permeable zone of the Lower Floridan aquifer. No karst collapse structures were identified in the seismic-reflection profiles acquired near the North District "Boulder Zone" Well Field. However, karst collapse structures at the level of the lowermost major permeable zone of the Lower Floridan aquifer at the South District "Boulder Zone" Well Field are present at three locations, as indicated by seismic-reflection data acquired in the $\mathrm{C}-1$ Canal bordering the south side of the injection facility. Results from the North District "Boulder Zone" Well Field well data indicate that a plausible hydraulic connection between faults and stratiform permeability zones may contribute to the upward transport of effluent, terminating above the base of the deepest U.S. Environmental Protection Agency designated underground source of drinking water at the North District "Boulder Zone" Well Field.

\section{Introduction}

The Miami-Dade Water and Sewer Department (MDWASD) injects treated domestic wastewater (effluent) into the saline Boulder Zone, a highly transmissive hydrogeologic unit within the Oldsmar Formation and the lower part of the Floridan aquifer system, through Class I injection wells at both the North District "Boulder Zone" Well Field (NDBZWF) and South District "Boulder Zone" Well Field (SDBZWF) (figs. 1-4). The depth of the Boulder Zone at the NDBZWF and SDBZWF ranges from about 2,750 to 3,300 feet below land surface (ft bls), whereas overlying permeable zones used as alternative drinking water supply range in depth from about 825 to $1,580 \mathrm{ft}$ bls at NDBZWF and SDBZWF. The injection wells introduce the effluent into the Boulder Zone beneath the deepest underground source 


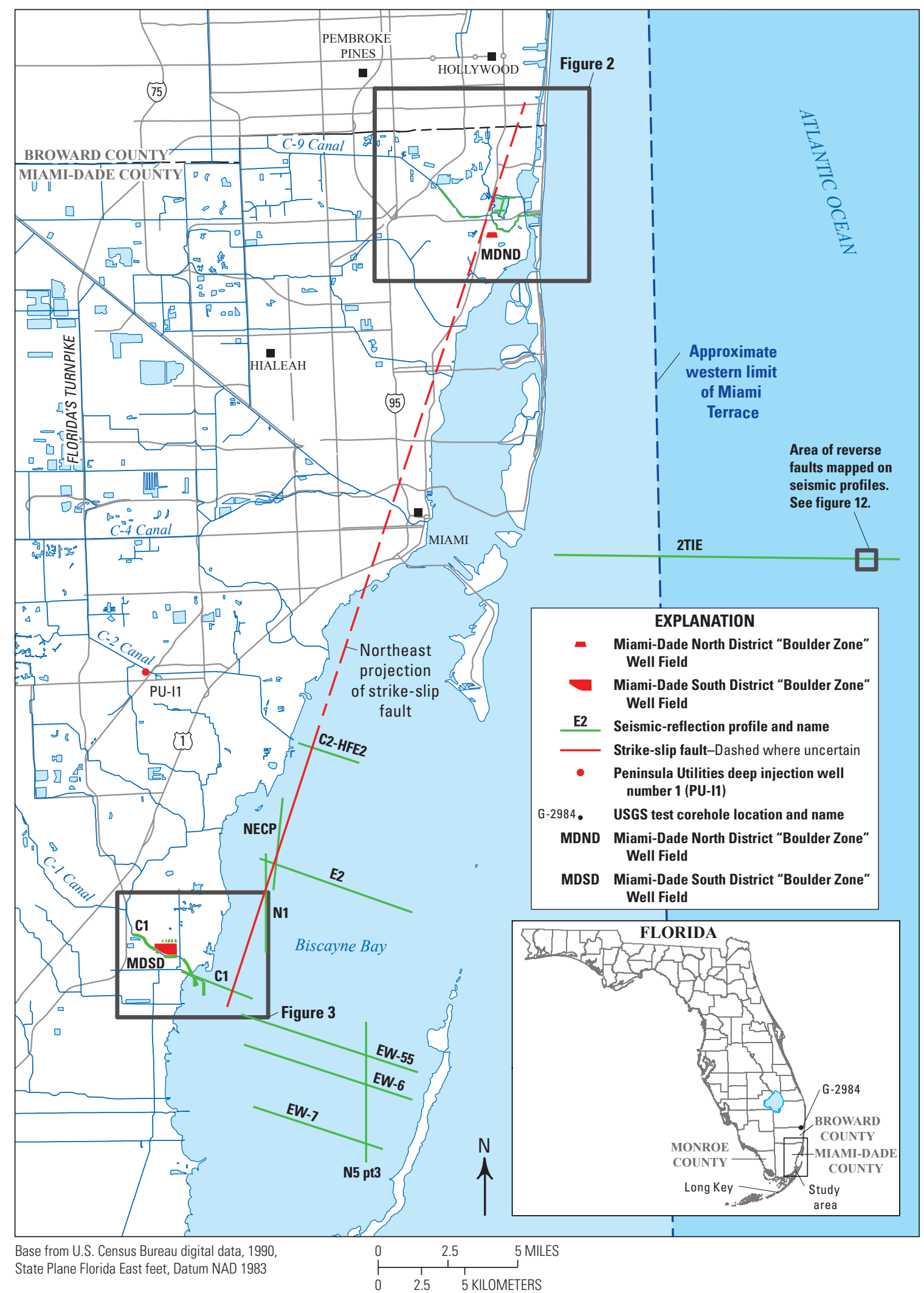

Figure 1. Location of Miami-Dade County, Florida, and the study areas that include the North and South District "Boulder Zone" deep-well areas. The deep-well areas are shown in more detail in figures 2 and 3 , respectively. 


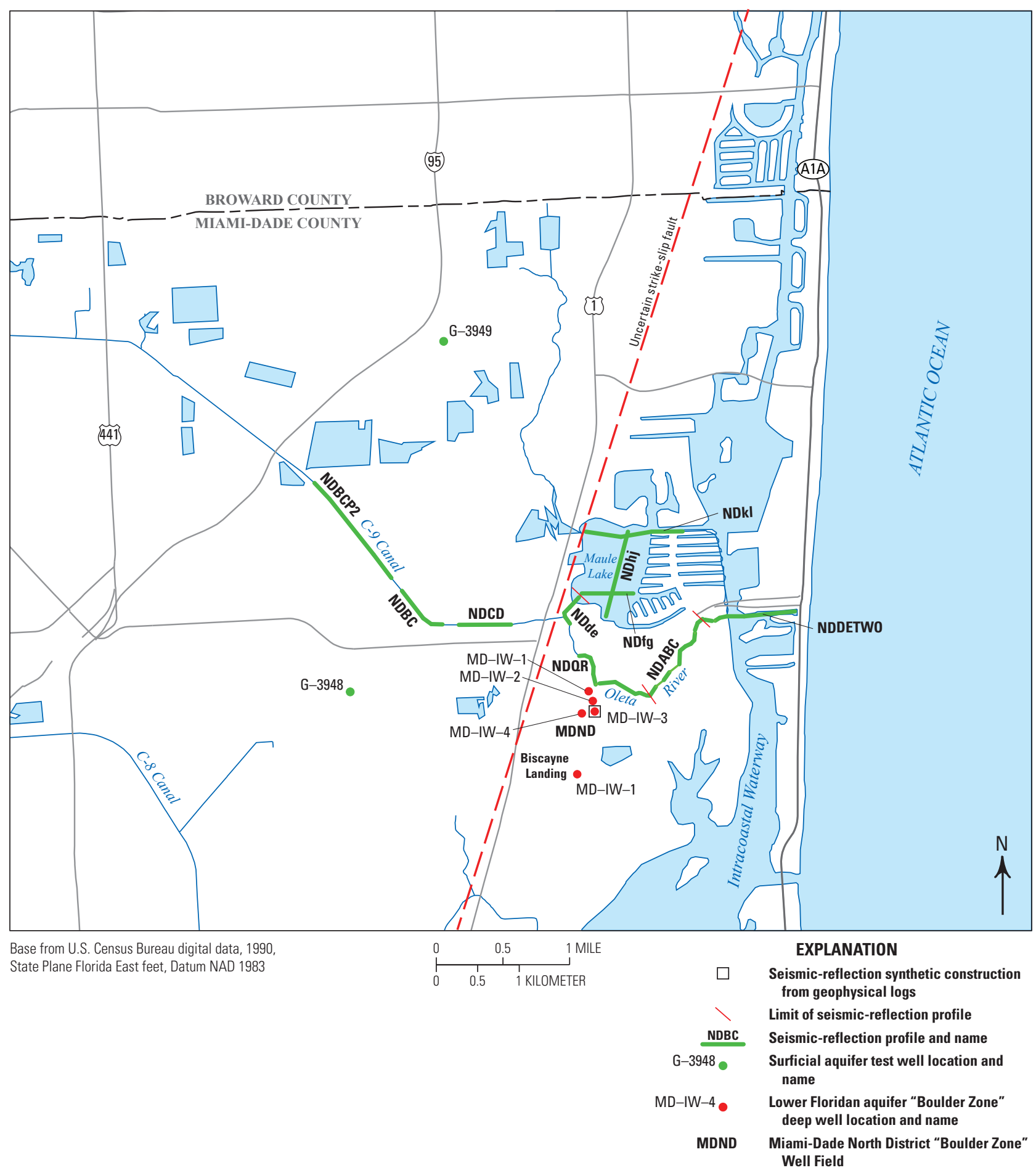

Figure 2. North District "Boulder Zone" deep-well area, where "Boulder Zone" deep wells MD-IW-1N through MD-IW-4N are located and the location of seismic-reflection survey profiles used in this study area. 


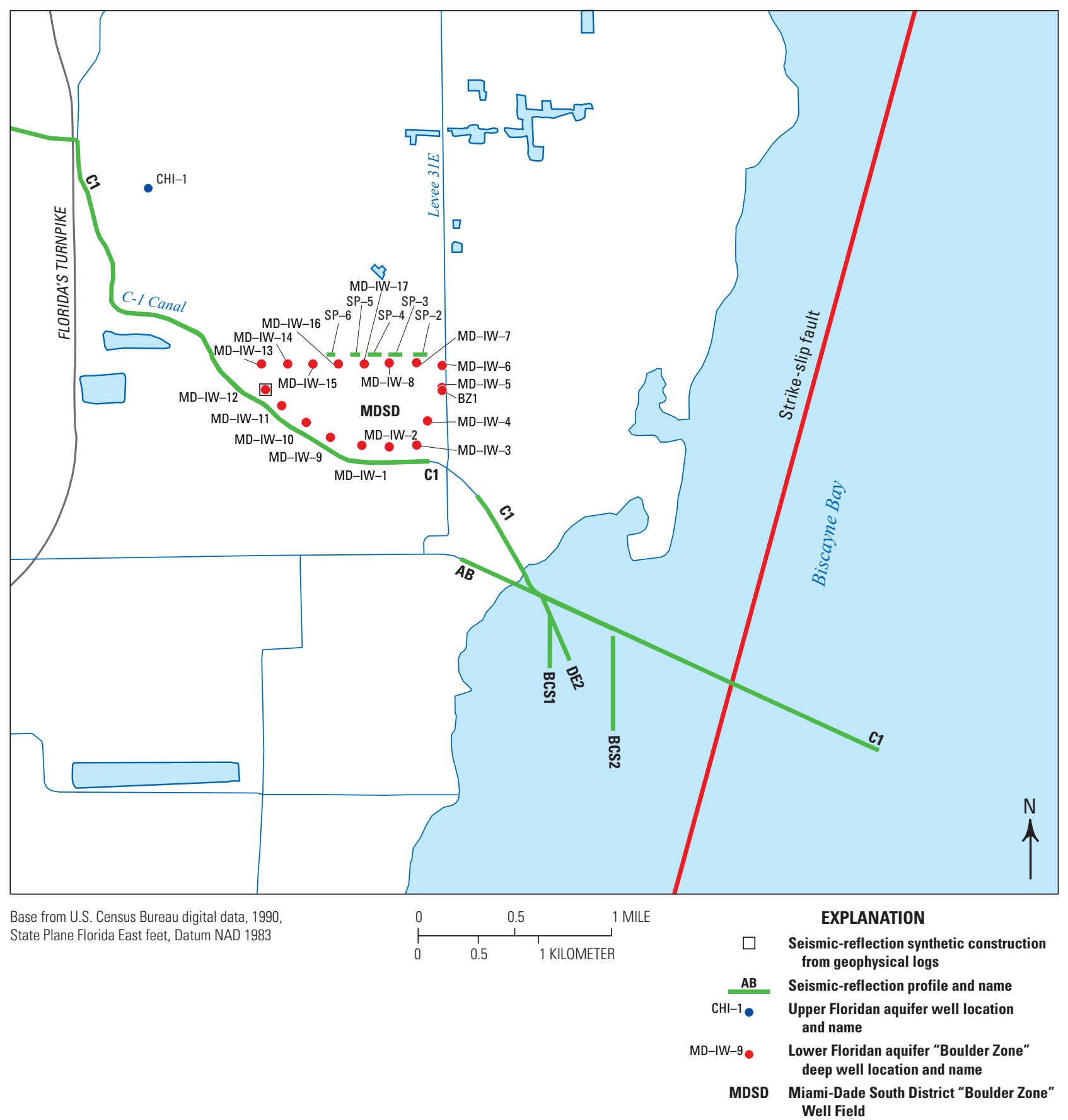

Figure 3. South District "Boulder Zone" deep-well area, where "Boulder Zone" deep wells MD-IW-1S through MD-IW-17S and BZ-1 are located and the location of seismic-reflection survey profiles used in this study area.

of drinking water (USDW), which is defined by the U.S. Environmental Protection Agency as an aquifer that contains a sufficient quantity of groundwater to supply a public water system and contains fewer than 10,000 milligrams per liter (mg/L) total dissolved solids (U.S. Environmental Protection Agency, 2013). At several wastewater injection facilities in southeastern Florida, effluent injected into the Boulder Zone has been detected at shallower depths in USDWs (Maliva and others, 2007), presenting a public health risk. For example, MDWASD has detected injected effluent above the base of the USDW at both the NDBZWF (J. King, U.S. Geological Survey, written commun., 2014) and SDBZWF (Walsh and Price, 2010). Within the Floridan aquifer system, buoyancy forces the upward vertical transport of injected effluent because native groundwater in the Boulder Zone is saline to brackish (both denser than non-saline groundwater) and injected effluent is non-saline (Maliva and others, 2007; Dausman and others, 2010; Walsh and Price, 2010). Confining strata above the Boulder Zone may be faulted, fractured, and influenced by karstic dissolution in 


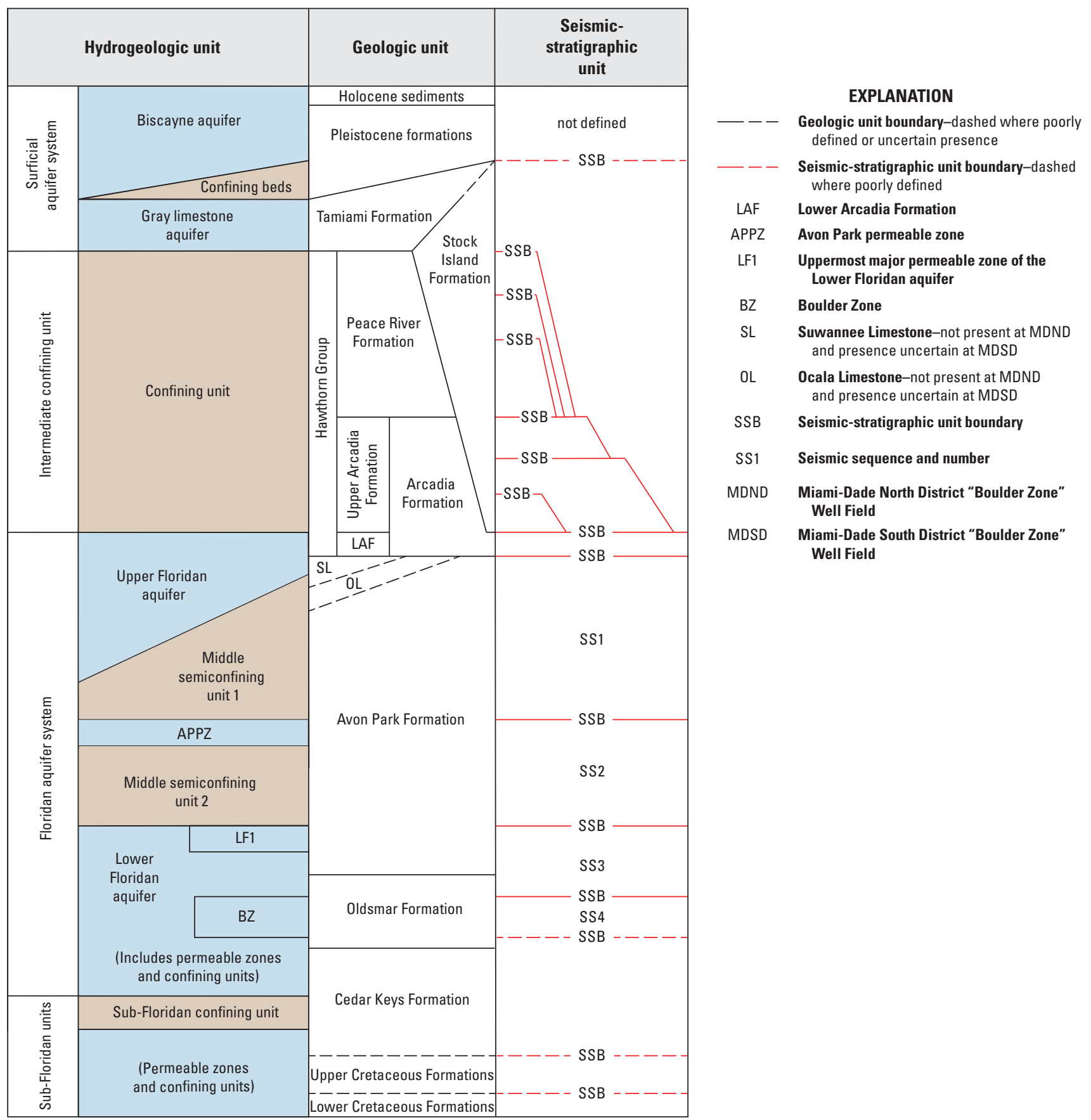

Figure 4. Correlation chart showing relations between hydrogeologic units, geologic units, and seismic-stratigraphic units (based on information from Reese and Richardson [2008], Roberts-Ashby and others [2013], and data presented herein). Seismicsequence boundaries shown on plates 1 and 2.

some areas of the Floridan aquifer system, facilitating effluent transport from the Boulder Zone to overlying permeable zones. Poor well construction also may enable effluent transport from injection zones to USDWs in the Floridan aquifer system.

In August 2008, the Florida Department of Environmental Protection required that MDWASD conduct a study of effluent injection into the Boulder Zone at the NDBZWF. The present study was initiated in 2009 by the U.S. Geological Survey (USGS), in cooperation with MDWASD, to support the overall investigation by providing geologic information about the stratigraphic and structural features that have the potential to contribute to the breaching of confining strata located above the Boulder Zone at the NDBZWF and SDBZWF. This study provides hydrogeologic conceptualizations (based on interpretations from recently acquired seismicreflection surveys) of potential physical pathways for upward migration of injected effluent that can be used to plan the development of future effluent-injection-well utilities in other areas of southeastern Florida. 


\section{Purpose and Scope}

The main purpose of this report is to characterize the seismic-sequence stratigraphy and geologic structure of the Floridan aquifer system at the NDBZWF and SDBZWF in Miami-Dade County, Florida. Seismic-sequence stratigraphic and structural interpretations are presented for both waterborne and land-based seismic-reflection surveys acquired near the two subsurface effluent injection facilities. Supporting interpretations are based on data from eight seismic-reflection profiles acquired between 2006 and 2011 in Biscayne Bay and the Atlantic continental shelf (figs. 1-3; Cunningham and Walker, 2009; Cunningham and others, 2012). Seismic-reflection interpretations were mostly verified by comparisons with geophysical and geological borehole data from the NDBZWF and SDBZWF. The goal of the interpretations is to improve current understanding of the relation between seismicsequence stratigraphy, imaged tectonic and karst structures, and the potential for vertical transport of injected effluent from the Boulder Zone upward into USDWs in southeastern Florida. The seismic-sequence stratigraphy and geologic structures presented herein represent the part of the Floridan aquifer system overlying and including the Boulder Zone; parts of the Floridan aquifer system underlying the Boulder Zone were not studied because of an absence of resolution in seismic-reflection profiles near the NDBZWF and SDBZWF. This poor seismic-reflection resolution is due to reductions in seismic energy, high-frequency seismic signal, and signal-tonoise ratio with increasing depth and within the Boulder Zone where highly irregular shapes and sizes of karst-produced megaporosity are present. The seismic-sequence framework and conceptualization of tectonic and karst seismic structures identified in the Floridan aquifer system should be useful to other hydrogeologic investigations in southeastern Florida where injection of effluent into the Floridan aquifer system is planned or in progress.

The foundations of seismic-sequence stratigraphy are the identification and characterization of seismic-reflection termination, configuration, continuity, and amplitude produced by sedimentary strata (Mitchum and others, 1977). Interpretation of the seismic-reflection data from southeastern Florida yielded a provisional seismic-sequence stratigraphy and information about the structural setting of the rocks of the Floridan aquifer system. In some cases, lithostratigraphic formation boundaries, depositional sequence boundaries, and hydrologic boundaries can be assigned to specific seismic reflections.

\section{Methods of Study}

To examine the seismic-sequence stratigraphy and geologic structures of the rocks of the Floridan aquifer system in the study area that includes NDBZWF and SDBZWF, waterborne and land seismic surveys were conducted during 2011 and 2012. In May 2011, Walker Marine Geophysical Company acquired about 5 miles (mi) of towed-streamer, high frequency, multichannel waterborne seismic-reflection data near the NDBZWF along the C-9 Canal, Oleta River, Intracoastal Waterway, and in Maule Lake (fig. 2). In June 2011, Walker Marine Geophysical Company collected about 11 mi of similar seismic-reflection data near the SDBZWF, along canals and in Biscayne Bay (fig. 3). Datacollection water depths ranged from approximately 1 to about $20 \mathrm{ft}$. A 23-ft shallow-draft vessel equipped with a proprietary MARDAQ25 digital-data acquisition system was used to acquire the seismic-reflection data with a dual air-gun source array and a 24-hydrophone streamer. Vessel speed was about 3 miles per hour. The digital sampling rate was between 4 and 10 kilohertz, shot spacing was $13 \mathrm{ft}$, data were sampled at 0.10 and 0.25 millisecond $(\mathrm{ms})$, and record length was typically 1.0-second (s) two-way traveltime, but in some cases 0.3-s two-way traveltime. A Trimble differential global positioning system acquired real-time positions. A land-based, seismic-reflection survey was acquired in January 2012 along a 2,740-ft transect on the northern side of the SDBZWF (fig. 3).

Waterborne seismic survey data near NDBZWF were processed by FairfieldNodal, near SDBZWF by Velseis Pty. Ltd., and land survey data were processed by Walker Marine Geophysical Company. Data processing included linear move out and filtering, deconvolution, velocity analysis, and true amplitude and post-stack migration. Final interpretation of processed seismic-reflection data employed Kingdom Suite SMT software and, in some cases, ROXAR RMS geomodeling software.

Synthetic seismograms provide a means to calibrate (groundtruth) seismic-reflection profiles to specific subsurface stratigraphic events observed in one-dimensional core and geophysical log data acquired from wells. Borehole compensated sonic logs (labeled "sonic velocity" in pl. 1) from injection wells MD-IW-3N at the NDBZWF, and MD-IW-12S at the SDBZWF were used to construct synthetic seismograms for each of the wells (pl. 1). The key synthetic seismogram used for correlation between well data at the NDBZWF and the waterborne seismic-reflection data acquired on the Oleta River was generated from well-log data acquired in the MD-IW-3N well (fig. 2). This well is about $0.2 \mathrm{mi}$ from where the waterborne seismic-reflection survey was acquired (fig. 2). A separate synthetic seismogram was used for correlation between well data collected at the SDBZWF and the waterborne seismic-reflection data acquired on the C-1 Canal and was generated from well-log data acquired in the MD-IW-12S injection well (fig. 3). This injection well is about $240 \mathrm{ft}$ from where the waterborne seismic-reflection survey was acquired (fig. 3). Velocity data from the sonic logs were converted to a synthetic seismic trace using Geokinetics, Inc. GdcMod software, reproduced 8 times, and placed side-by-side to resemble a seismic-reflection profile (synthetic seismograms shown in pl. 1). For each well, its synthetic seismogram was used to relate geologic and geophysical well data to seismic-reflection data. Stratigraphic and hydrogeologic interfaces were fit to the true wavelet traces on seismic-reflection profiles (pl. 1). Selected stratigraphic and hydrogeologic interfaces were identified on the basis 
of comparisons to published geologic and hydrogeologic frameworks (fig. 4; Reese and Richardson, 2008; Reese and Cunningham, 2013, 2014). The direct correlation of key traces on the synthetic seismograms to seismic-reflection profiles was not a perfect fit (pl. 1). For example, a high-amplitude positive wavelet (right side of wavelet is filled in black) marking the top of seismic sequence 3 on the synthetic seismogram for the IW-12 well is located at a slightly lower altitude than the corresponding high-amplitude positive wavelet at the projected position of the IW-12 well on the seismic-profile $B-B^{\prime}$ (pl. 1). Some disparity is common between synthetic seismograms and seismic-reflection profiles (Bruns and others, 1994) and, in many cases, is a result of imperfect modeling of synthetic seismograms.

\section{Geologic Setting of the Floridan Aquifer System}

The broad geologic setting of the rocks surrounding and composing the Floridan aquifer system (fig. 4) was characterized using selected hydrogeologic, lithostratigraphic, tectonic, and structural system information. Such information is used to better delineate the lithostratigraphic units that compose much of the Floridan aquifer system in southeastern Florida, thereby enabling more accurate identification of these hydrogeologic and lithostratigraphic units within the new seismic-reflection data. Additionally, highlighting the tectonic and structural history of southeastern Florida and adjacent areas is important for providing realistic interpretations of the structural features, imaged in the seismic-reflection data, that could affect the fate of effluent injection into the Boulder Zone at the NDBZWF, SDBZWF, and elsewhere in southeastern Florida.

\section{Hydrogeology}

An accurate representation of the hydrogeologic and lithostratigraphic framework of the Floridan aquifer system is critical to understanding the confinement and transport of injected effluent at the NDBZWF, SDBZWF, and elsewhere in southeastern Florida. A vertical succession of upper Paleocene to upper Oligocene or upper Paleocene to lower Miocene lithostratigraphic units between depths of approximately 3,600 to about $850 \mathrm{ft}$ bls and of varying permeability compose the Floridan aquifer system at the NDBZWF and SDBZWF (fig. 4; Miller, 1986, pls. 26 and 33). At the NDBZWF, these units include the upper Cedar Keys Formation (Miller, 1986), Oldsmar Formation, Avon Park Formation (Reese and Richardson, 2008), and a lower part of the Arcadia Formation of the Hawthorn Group (fig. 4). At the SDBZWF, these units include the upper Cedar Keys Formation (Miller, 1986), Oldsmar Formation, Avon Park Formation (Reese and Richardson, 2008), possibly the Ocala Limestone (Miami-Dade County, 1996), possibly the Suwannee Limestone (Reese and Richardson, 2008, pl. 4), and a lower part of the Arcadia Formation (fig. 4). This lower part of the Arcadia Formation corresponds to the informal lower Arcadia Formation delineated in nearby Broward County by Reese and Cunningham (2014, pls. 1-3 and fig. 14). Reese and Richardson (2008) delineated and assigned a hydrostratigraphic nomenclature to permeable zones and confining units of the Floridan aquifer system for southern Florida, and Reese and Cunningham (2013) delineated and assigned a hydrostratigraphic nomenclature to permeable zones and confining units of the Floridan aquifer system for Broward County (fig. 1). The permeable zones and associated hydrogeologic nomenclature defined for Broward County (Reese and Cunningham, 2013, 2014) served as a framework for mapping the permeable zones at the NDBZWF, SDBZWF, and on offshore seismic-reflection profiles. Major permeable zones defined at the NDBZWF and SDBZWF are the Upper Floridan aquifer, Avon Park permeable zone, uppermost major permeable zone of the Lower Floridan aquifer, and Boulder Zone (fig. 4). Each permeable zone was identified on seismicreflection profiles at the NDBZWF, SDBZWF, and offshore, where correlation to well data indicated that it is possible to map the four permeable zones at a regional scale using seismic-reflection data.

\section{Avon Park Formation-Arcadia Formation Contact in the Area of the North and South District "Boulder Zone" Well Fields}

Several authors have recognized the presence of the Suwannee Limestone between the top of the Avon Park Formation and base of the Arcadia Formation in eastern Miami-Dade County and in northeastern Broward County, and have included it as part of the Floridan aquifer system (Miller, 1986: Reese, 1994; Reese and Richardson, 2008). Observations made as part of this study provide no evidence for the presence of the Suwannee Limestone at the NDBZWF study area; to the north, work by Reese and Cunningham $(2013,2014)$ did not identify the Suwannee Limestone in eastern Broward County. The work of Reese and Cunningham $(2013,2014)$ indicated that lithologic and gamma-ray log intervals in the formation reported to be Suwannee Limestone by Miller (1986), Reese (1994), and Reese and Richardson (2008) were actually the lower Arcadia Formation. Miller (1986) reported a lithologic description and gamma-ray log interval acquired from the PU-I1 well in Miami-Dade County (fig. 1) that was interpreted as Suwannee Limestone. Reese (1994) also employed lithology and gammaray logs to define an interval in wells that was interpreted as the Suwannee Limestone in Miami-Dade County.

For comparison of the southern Florida Suwannee Limestone lithologies to the Arcadia Formation lithologies at the NDBZWF and SDBZWF, the closest known core samples of Suwannee Limestone are from a continuously cored interval about $100 \mathrm{ft}$ thick through the top of a formation in test corehole W-17156 on Long Key, Monroe 
County (fig. 1; Cunningham and others, 1998). Principal carbonate grains in core samples are skeletal fragments, mollusks, miliolids, peloids, Halimeda, corals, and peneroplids (Cunningham and others, 1998). Cunningham and others (1998) defined the following lithofacies for the Suwannee Limestone core samples, based on particle composition and depositional texture: (1) skeletal floatstone and rudstone, (2) coral framestone and floatstone, (3) molluscan rudstone and floatstone, (4) peloid grainstone and packstone, (5) benthic foraminifer grainstone, (6) Halimeda rudstone and floatstone, and (7) peneroplid packstone. Carbonate particles of the seven lithofacies define a photozoan association, which is commonly consistent with deposition in a tropical environment inside the photic zone (James, 1997, fig. 4). Cunningham and others (1998) did not observe phosphorite grains in core samples of the Suwannee Limestone. This is an important observation because Scott (1988) placed the base of the Arcadia Formation at the deepest occurrence of a sandy, variably phosphatic carbonate in southern Florida, which contrasts with coarser-grained, non-phosphatic, non-quartz sand bearing, and non-dolomitic Suwannee Limestone, characteristics also noted for the Suwannee Limestone beneath the Florida Keys by Cunningham and others (1998). In general, Scott (1998) described the lithology of the Arcadia Formation as principally limestone and "dolostone," including varying amounts of quartz sand, clay, and "phosphate" grains. He reported that the Hawthorn Group overlies the Suwannee Limestone throughout much of southern Florida. Cunningham and others (1998) reported only a sporadic occurrence of quartz grains that ranged from absent to 1 percent in the Suwannee Limestone. Moreover, Cunningham and others (1998) identified no quartz in Suwannee Limestone cores in measurements made with an $\mathrm{x}$-ray diffractometer and the authors measured minor dolomite in only one bulk-core sample.

Reese and Cunningham (2014, pls. 1-3) showed that both the Ocala Limestone and Suwannee Limestone are absent in eastern Broward County and that the Arcadia Formation overlies the Avon Park Formation across a major unconformity and depositional sequence boundary. Dominant carbonate particle types in the lower Arcadia Formation in samples from a northeastern Broward County test corehole G-2984 (fig. 1; Reese and Cunningham, 2014) are bivalves, benthic foraminifera, bryozoan, and echinoids. These particle types define a heterozoan association, which can be indicative of subtropical or cooler seawater conditions during deposition (James, 1997, fig. 4). In some cases, salinity and nutrient supply also influence the dominance of heterozoan particles in carbonate sediments (James, 1997). The observed heterozoan association in samples from the lower Arcadia Formation in test corehole G-2984 contrasts markedly with the photozoan association described for Suwannee Limestone samples from test corehole W-17156 (fig. 1; Cunningham and others, 1998, fig. 1). Quartz sand, phosphorite grains, and dolomite were commonly observed in core samples and thin sections acquired from the lower Arcadia Formation in test corehole G-2984; phosphorite was absent, however, and quartz sand and dolomite were scarce in samples of Suwannee Limestone collected from Florida Keys test corehole W-17156. For the MD-IW-I3N well at the NDBZWF (fig. 2), the Miami-Dade Water and Sewer Department (2002) described the lithology of well cuttings assigned to the Hawthorn Group as phosphatic to very phosphatic limestone that directly overlies the limestone of the Avon Park Formation. The lithologic information reported by Miami-Dade Water and Sewer Department (2002) indicates that the Suwannee Limestone is absent at the NDBZWF and the Arcadia Formation is in direct contact with the Avon Park Formation.

The gamma-ray log character of the informal lower Arcadia Formation (as defined by Reese and Cunningham [2014] in Broward County) at the NDBZWF and SDBZWF has a similar geometry and intensity, compared to logs across the lower Arcadia Formation in eastern Broward County, as exemplified by data from the G-2984 well (Reese and Cunningham, 2014, fig. 8). Although many investigators have reported the presence of Suwannee Limestone in southern Florida (Parker and Cooke, 1944; Applin and Applin, 1944; Puri and Winston, 1974; Miller, 1986; Reese, 1994; Reese and Richardson, 2008), recent studies by the Miami-Dade Water and Sewer Department (2002) and Reese and Cunningham $(2013,2014)$ have determined that both the Ocala Limestone and Suwannee Limestone are absent, and the Arcadia Formation directly overlies the Avon Park Formation in eastern Broward County and at the NDBZWF. The presence of the Ocala Limestone at the SDBZWF was suggested by the Miami-Dade Water and Sewer Department (1996), and Reese and Richardson (2008) delineated the presence of the Suwannee Limestone at the SDBZWF. However, comparison of the gamma-ray character in the MD-IW-12S well (Reese and Richardson, 2008, pl. 4) at SDBZWF to the G-2984 (Reese and Cunningham, 2014, fig. 8) gamma-ray character of the lower Arcadia Formation in Broward County (where both optical borehole wall images and continuously drilled core samples are available over much of the lower Arcadia Formation) indicates that the Ocala Limestone and Suwannee Limestone may not be present at the SDBZWF.

Precise age dating of the rocks in the lower Arcadia Formation could further substantiate the absence of the Suwannee Limestone in northeastern Miami-Dade County, but none exists for this area. Brewster-Wingard and others (1997), and Guertin and others (2000) assigned the Suwannee Limestone in southern Florida to the early Oligocene. Guertin and others (2000), and Cunningham and others (2003) dated the lower Arcadia Formation as late Oligocene at test coreholes in southwestern and south-central Florida, respectively. However, Brewster-Wingard and others (1997) reported that the lower Arcadia Formation is as old as the middle of the early Oligocene at some locations in southwestern Florida. Guertin and others (2000) reported the lower Arcadia Formation as early Miocene at test corehole W-17156 (fig. 1). Because there is no general agreement on the age of the lower Arcadia Formation in southern Florida, it is unclear whether the lower Arcadia Formation is of Oligocene or early Miocene age at the NDBZWF and SDBZWF. 


\section{Tectonic and Structural Setting of the Florida Platform}

The development of the tectonic and structural aspects of the Florida Platform is a critical geologic element in the confinement and transport of injected effluent at the NDBZWF and SDBZWF. The Florida Platform is composed of about 6,600 to $20,000 \mathrm{ft}$ of shallow-water carbonate and evaporite deposited during cycles of sedimentation and subsidence (Hine, 2009, 2013). The thick sedimentary deposits overlie igneous and metasedimentary rocks that compose two basement blocks of different origins: the Suwannee basin block, under central and northern peninsular Florida; and the Florida-Bahama block, under southern Florida (fig. 5; Horton and others, 1991; Hine, 2013). Hine (2009) proposed that both blocks were exotic terranes derived from the supercontinent Pangaea. During the late Paleozoic to early Mesozoic, the Suwannee basin block was part of northwestern Africa (Dallmeyer, 1989) and the Florida-Bahama block was possibly part of South America (Hine, 2009). The Florida Platform overlying the Florida-Bahama block began to build during the Late Jurassic, with the deposition of sediments above a post-rift unconformity caused by the initial opening of the early Atlantic Ocean during the breakup of Pangaea (Klitgord and others, 1984). The Suwannee basin block and FloridaBahama block formed a southeastern element of the trailing edge - or passive margin — of the North American plate. The tectonic history of these two blocks has been relatively quiescent since formation (Smith and Lord, 1997), compared to the leading edge - or active west coast margin — of the North American plate.

From the Mesozoic through the Cenozoic much of the sediment deposited on the Florida Platform was composed of carbonate sediment. During the Mesozoic, the Florida Platform was part of a carbonate mega-platform that spanned the Yucatan Peninsula to the southwest and Nova Scotia to the north (Hine, 2009, 2013). The platform reached its maximum extent during the Late Jurassic and Early Cretaceous, when siliciclastic sedimentation along the continental margin of North America buried the northern extent of the platform

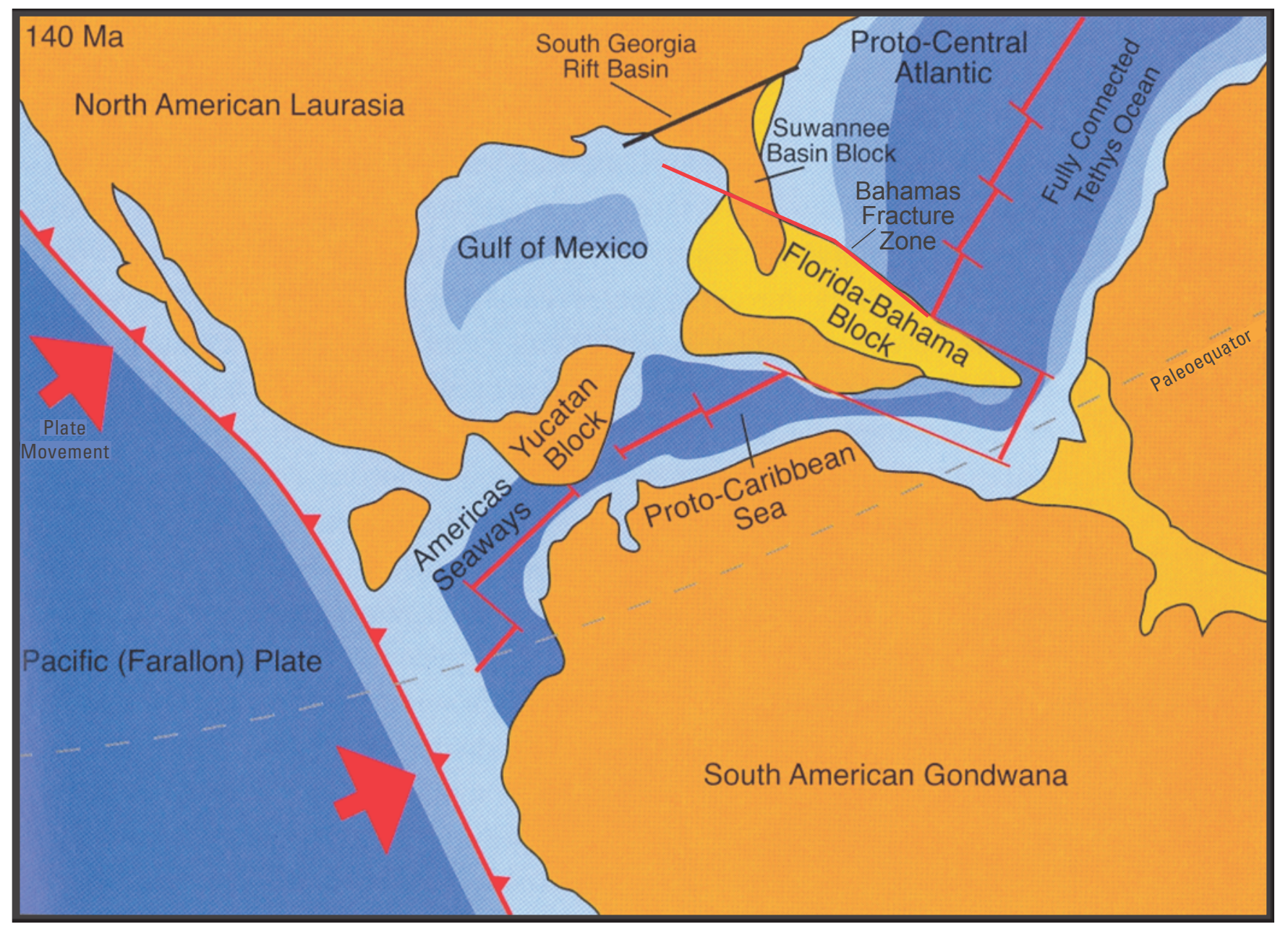

Figure 5. Conceptualized paleogeography about 140 Mya depicting a fully assembled Florida basement. Seafloor spreading has since ended in the Gulf of Mexico and movement of the Yucatan and Florida-Bahama blocks has ceased. Modified from Ross and Scotesse (1988); reprinted and modified with written permission from Elsevier Limited, Oxford, United Kingdom. Bahamas fracture zone from Klitgord and others (1984) and Horton and others (1991). 
(Poag, 1991). During much of the time from the late Oligocene to Pliocene, terrigenous clastic deposition extended from northern Florida to the southern area of the platform (Enos and Perkins, 1977; Warzeski and others, 1996; Cunningham and others, 2003). Carbonate sedimentary deposits dominated the Florida Keys region during the Pleistocene.

Sproul and others (1972), Miller (1986), Duncan and others (1994), Reese (1994), Mitchell-Tapping and others (1999), and Cunningham and others (2012) documented faulting in the Eocene carbonate rocks of the Florida Platform that compose a major part of the of Floridan aquifer system. The authors did not explain the forcing mechanisms that created the faults, with the exception of Cunningham and others (2012), who identified faults in southeastern Florida as being related to tectonic movement. Tectonic faults observed in southeastern Florida (Cunningham and others, 2012) may be due to movement throughout the Bahamas fracture zone, which Klitgord and others (1984) reported as connecting the spreading center in the central Atlantic Ocean with a spreadingcenter system in the Gulf of Mexico (fig. 5). As an alternative forcing mechanism for tectonic faulting in southern Florida, Missimer and Maliva (2004) offered evidence for late Miocene to Pliocene tectonic compression in the Tertiary sedimentary section of the southern part of the Florida Platform, which the authors suggested was related to peripheral responses to tectonic events in the Caribbean Basin. The origin of tectonic faults in southeastern Florida is discussed further in the Tectonic Faults section of this report.

Similar to many ancient carbonate platforms around the world (Budd and others, 1995), the Florida Platform has been exposed to episodes of karstification, which in many cases has enhanced porosity and permeability. Numerous karst collapse structures in the carbonate rocks of the southeastern part of the Florida Platform have been delineated in the rocks of the Floridan aquifer system and imaged on seismic-reflection profiles interpreted by Cunningham and Walker (2009), Cunningham and others (2012), Cunningham (2013), and Reese and Cunningham $(2013,2014)$. Examples of similar karst collapse structures identified in the southeastern part of the Florida Platform include those in the following areas: (1) northeast Florida (Kindinger and others, 2000; Spechler, 2001), (2) La Belle area of the Caloosahatchee River (Cunningham and others, 2001b), (3) Tampa Bay and Charlotte Harbor in west-central Florida (Missimer and Gardner, 1976; Evans and Hine, 1991; Hine and others, 2009), (4) northeast Florida shelf (Popenoe and others, 1984), and (5) the central Florida sinkhole district (Evans and others, 1994).

\section{Seismic-Sequence Stratigraphy of the Floridan Aquifer System}

A major result of the seismic-sequence stratigraphy analysis was the identification of four provisional seismic sequences (seismic sequences 1-4) that extend vertically from the upper part of the Floridan aquifer system to near the base of the of Floridan aquifer system (fig. 4). The hydrogeologic framework established by Reese and Richardson (2008) for central and southern Florida, and Reese and Cunningham $(2013,2014)$ for eastern Broward County was linked to the four seismic sequences (fig. 4), as identified in well data from the NDBZWF and SDBZWF areas (figs. 2 and 3, pls. 1 and 2). The tops of the seismic sequences correspond to both a lithostratigraphic formation and major cyclostratigraphic top or to the general location of a hydrogeologic unit top. The top of seismic sequence 1 corresponds with the top of the Avon Park Formation, the top of seismic sequence 2 with the approximate location of the top of the Avon Park permeable zone, the top of seismic sequence 3 with the approximate position of the top of the uppermost major permeable zone of the Lower Floridan aquifer, and the top of seismic sequence 4 with the approximate location of the top of the Boulder Zone (fig. 4). The top of the lower Arcadia Formation is also a prominent seismicsequence boundary and depositional sequence boundary (pl. 1) that Reese and Cunningham (2014) identified. It is common for the top of the Floridan aquifer system to occur within the lower Arcadia Formation in southeastern Florida (fig. 4, Reese and Richardson, 2008; Reese and Cunningham, 2014). This preliminary seismic-sequence nomenclature may be revised as the scope of USGS investigation in southeastern Florida broadens in future studies.

\section{Seismic-Sequence Stratigraphy of the Arcadia Formation and Stock Island Formation}

The seismic-sequence stratigraphy of the Arcadia Formation and Stock Island Formation is important to the delineation of the uppermost part of the Floridan aquifer system and lower part of the intermediate confining unit in southeastern Florida. Seismic-reflection profiles in a western part of the NDBZWF study area imaged low-angle, east dipping ( $1-2^{\circ}$ apparent dip), clinoformal reflections (sloping reflections, commonly indicative of progradation of strata into deeper water) assigned to the informal upper Arcadia Formation (cross-section $A-A^{\prime}$, pl. 1), as defined by Reese and Cunningham (2014, pls. 1-3) in Broward County. In the western part of the NDBZWF study area, these reflections downlap (defined as the termination of more steeply dipping overlying reflections against a reflection surface that has lower apparent dip) onto the upper surface of the lower Arcadia Formation (cross-section $A-A^{\prime}$, pl. 1). In an eastern part of the NDBZWF study area, seismic-reflection profiles show low-angle, east dipping, clinoformal reflections assigned to the Stock Island Formation (cross-section $A-A^{\prime}$, pl. 1). The presence of the Stock Island Formation between the base of the Tamiami Formation and top of the lower Arcadia Formation was confirmed by comparison of the lithology of the type section of the Stock Island Formation on Stock Island in the Florida Keys (Cunningham and others, 1998, fig. 1) to lithologic descriptions presented for MD-IW-3N at NDBZWF (Miami-Dade Water and Sewer Department, 2002) and IW-1 at 
Biscayne Landing (CH2MHILL, 2013) (fig. 2). The reflections of the Stock Island Formation overstep the clinoformal reflections of the upper Arcadia Formation and downlap onto the upper bounding surface of the lower Arcadia Formation (pl. 1). In the NDBZWF study area, the thicknesses of the clinoformal reflections that compose the upper Arcadia Formation and Stock Island Formation are about 100 ms two-way travel time and approximately $150 \mathrm{~ms}$ two-way traveltime, respectively (cross section $A-A^{\prime}$, pl. 1).

Eastward dip on reflection-clinoform sets assigned to the Arcadia Formation and Stock Island Formations (cross-section $A-A^{\prime}$, pl. 1) indicate eastward progradation of both sets corresponding to the carbonate ramps (Pomar, 2001, fig. 15) that compose both of these formations. Reflection clinoforms of the Stock Island Formation are more steeply dipping (up to $4^{\circ}$ apparent eastward dip) than those of the reflection clinoforms Arcadia Formation ( $1-2^{\circ}$ apparent dip). The upper surface of lower Arcadia Formation is an unconformity and represents a very long depositional hiatus separating the accumulation of carbonate and siliciclastic sediments of the lower Arcadia Formation and quartz-grain-bearing carbonate strata (Miami-Dade Water and Sewer Department, 2002) of the superjacent Stock Island Formation. The hiatus is about 14-16 million years, as established by chemostratigraphic, paleontologic, and paleomagnetic age dating of the Arcadia Formation and Stock Island Formation (assuming the Stock Island Formation is a deeper water facies of the Tamiami Formation) beneath southern Florida (Cunningham and others, 2003; Guertin and others, 2000). This protracted depositional hiatus indicates that the sequence boundary at the top of the lower Arcadia Formation is present over a widespread area. Core samples from USGS test corehole G-2984 in northeastern Broward County (Cunningham, 2013, fig. 3), indicate that the sequence boundary at the top of the lower Arcadia Formation is a drowning unconformity (Cunningham, 2013; Schlager, 1989, 1999). Reese and Cunningham (2013), and Cunningham (2013) show that the top of this sequence boundary at the top of the lower Arcadia Formation is phosphatized, indicating sediment starvation and drowning by nutrient-rich seawater prior to deposition of overlying carbonate sediments (for example, Schlager, 1999).

\section{Seismic Sequence 1}

Seismic sequence 1 comprises rocks between the top of the Avon Park Formation and rocks at or near the top of the Avon Park permeable zone (fig. 4, pl. 1). Seismic sequence 1 ranges in thickness from about 85 to roughly $130 \mathrm{~ms}$ two-way traveltime (fig. $6 A-B$, pl. 1). Horizontal, parallel seismicreflection geometries with moderate-to-very-good reflection continuity characterize reflection configurations of seismic sequence 1 (fig. $6 A-B$ ). Reflections generally have the highest amplitudes in the uppermost part of seismic sequence 1 . Seismic sequence 1 is composed of multiple stacked reflection-cycle sets, wherein each set displays an upward increase in amplitude (fig. 6B). No notable broad U-shape or V-shaped seismic-reflection configurations appeared in data from the NDBZWF or SDBZWF study areas, or on 2TIE; however, beneath Biscayne Bay, narrow to very broad V-shaped reflection configurations up to about $3 \mathrm{mi}$ in diameter span upward from underlying seismic sequences into seismic sequence 1 (for example, fig. 7).

Stacked cyclicity of upward increasing reflection amplitudes, moderate-to-very-good reflection continuity, and parallel reflection configurations (fig. $6 A-B$ ) are consistent with vertical stacking of shallow-marine platform carbonates (Macurda, 1997). Karst collapse structures are not present in seismic sequence 1 near the NDBZWF or SDBZWF, or on 2TIE, as indicated by an absence of inverted V-shaped sagging reflection configurations. However, the presence of the up to 3-mi-wide, inverted V-shaped refection configurations along seismic-reflection line N5-pt3, acquired in Biscayne Bay (figs. 1 and 7), indicates that faulting and fracturing related to karst-collapse probably occur locally within seismic sequence 1.

\section{Seismic Sequence 2}

Seismic sequence 2 is characterized by continuous-todiscontinuous, subhorizontal, parallel-to-wavy or hummocky reflection configurations having the greatest amplitudes and reflection continuity at or near the top of the sequence (fig. $6 C-D$ ). In general, chaotic reflection patterns are not common within seismic sequence 2 at the SDBZWF nor on seismic-refection profile 2TIE (fig. $6 C-D$ ) but are common at the NDBZWF (pl. 1). Seismic-reflection configurations on seismic-reflection profile 2TIE exhibit horizontal, parallel geometries having good reflection continuity (fig. 6D). On seismic-reflection profile 2TIE, seismic sequence 2 is composed of two stacked reflection cycles with average thicknesses ranging from about 50 to approximately $80 \mathrm{~ms}$ two-way traveltime (fig. $6 D$ ). Both reflection-cycles show upward increases in amplitude (fig. $6 D$ ). East of the SDBZWF and beneath Biscayne Bay, on seismic-reflection profile N5-pt3 (fig. 1), stacked seismic reflections form a broad, inverted $\mathrm{V}$-shape throughout the vertical extent of seismic sequence 2 across a horizontal distance of about $3 \mathrm{mi}$ (fig. 7). On seismic-reflection profile EW7 (fig. 1), basal reflections of seismic sequence 1 onlap (defined as the termination of shallowly dipping, younger reflections against more steeply dipping underlying reflections) onto the upper bounding reflection surface of seismic sequence 2 and basal reflections of seismic sequence 2 onlap onto the upper bounding reflection surface of seismic sequence 3 (fig. 8).

The top of the Avon Park permeable zone and top of the uppermost major permeable zone of the Lower Floridan aquifer bound the top and base of seismic sequence 2 (fig. 4), respectively. Strong continuity in parallel seismic reflections throughout seismic sequence 2 is consistent with the presence of stacked shallow-marine platform carbonates (Macurda, 1997). Broad, inverted V-shaped seismic-reflection configurations to the east of the SDBZWF 


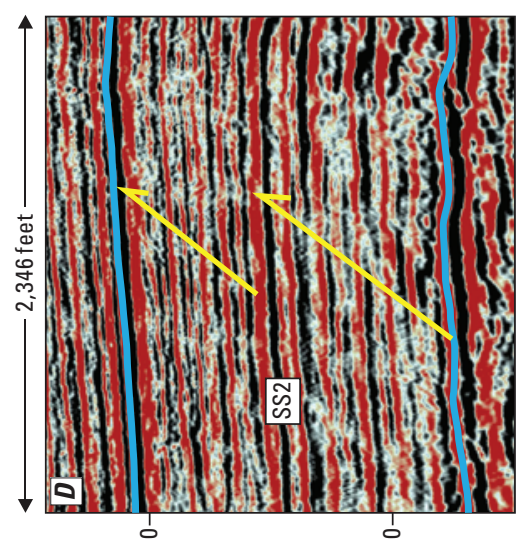

:
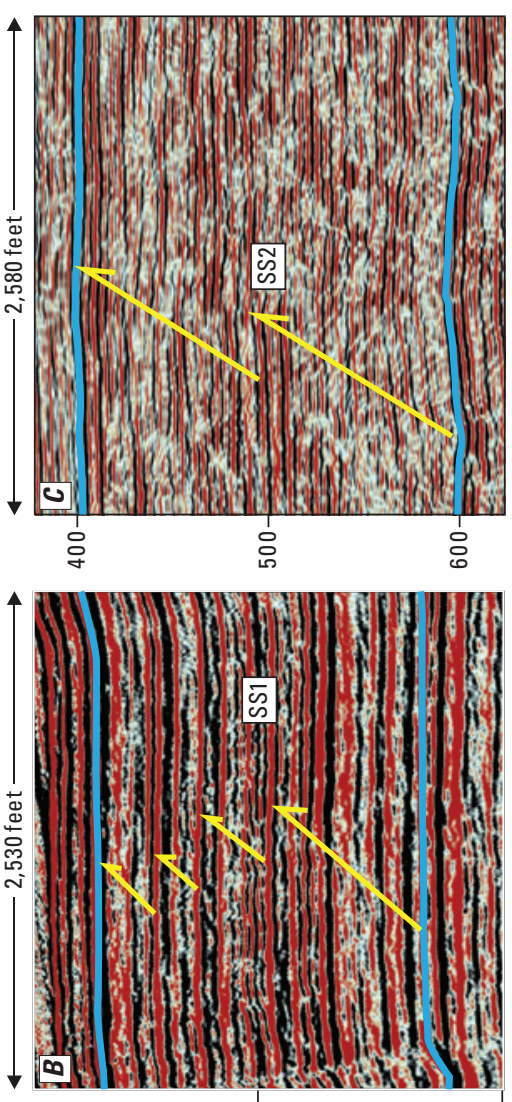

宫

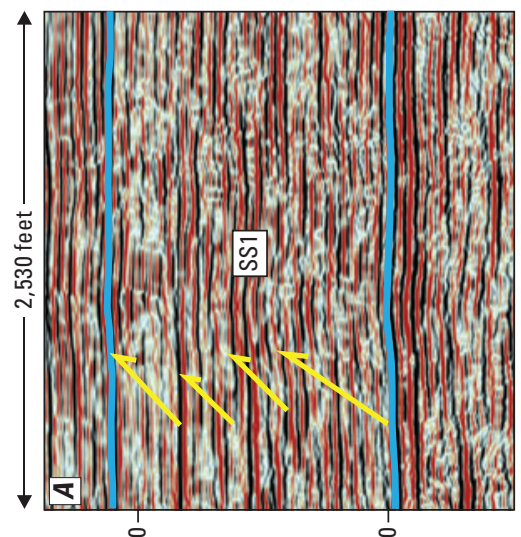

总

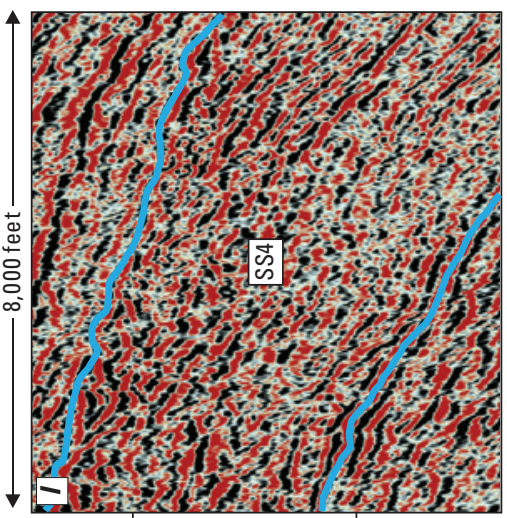

今

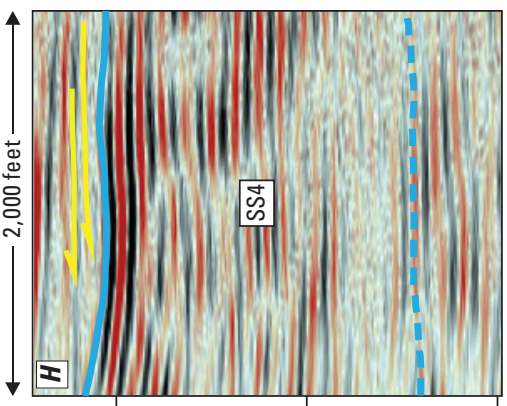

웅
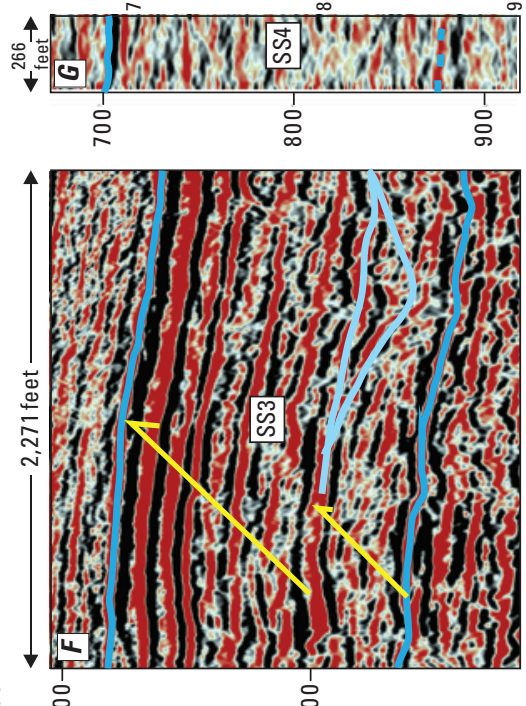

$\stackrel{8}{\circ}$

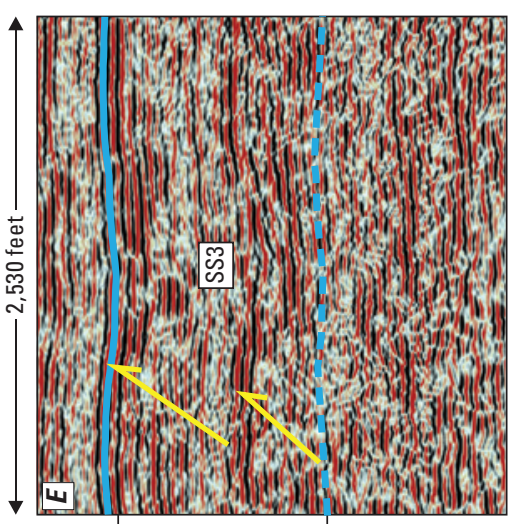

:

옹

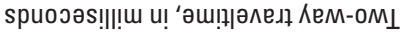

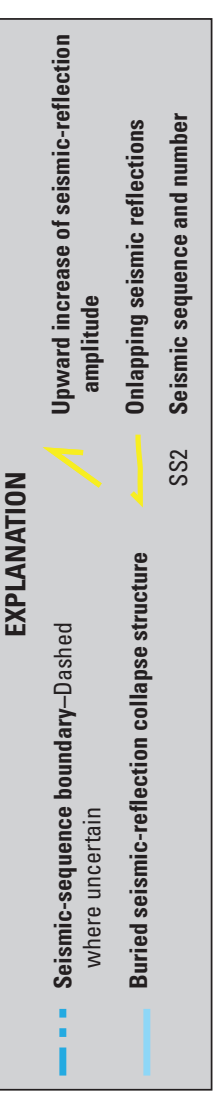

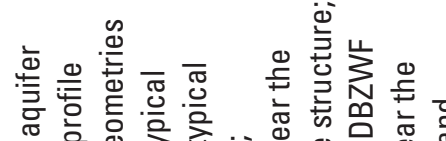

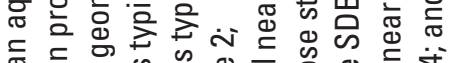

要

흔

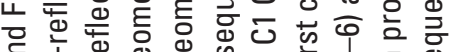

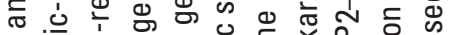

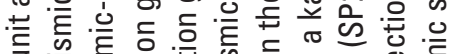

类

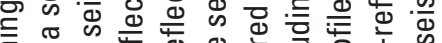

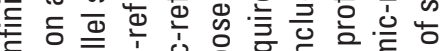

항

ब

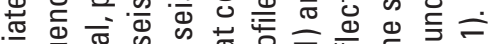

क्षे

E

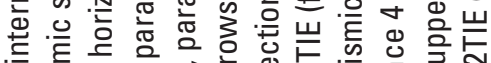

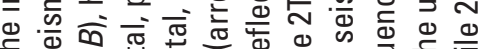

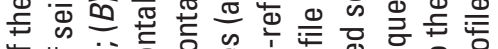

능

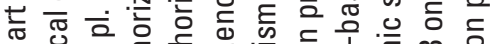

은.을

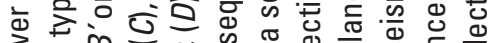

合 0

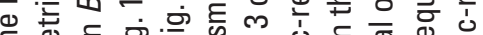

要

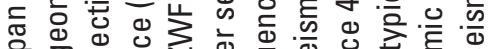

क力

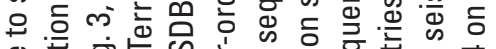

过宝! cs

言 专

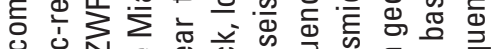

들

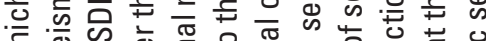

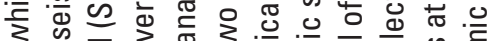

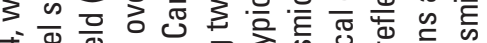

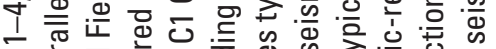

\&

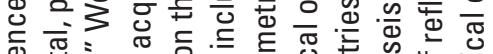

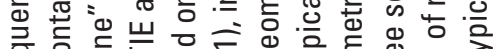

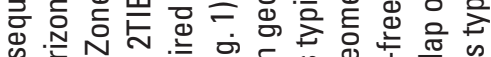

o

辰

类立棓 음

क ه

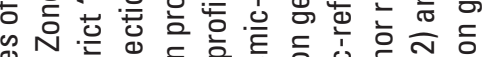

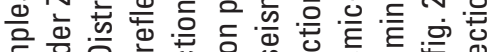

흘 흘

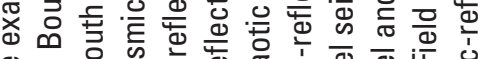

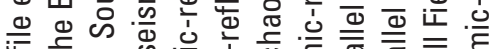

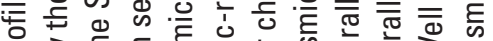

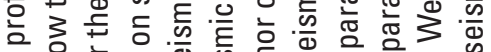

ᄃ

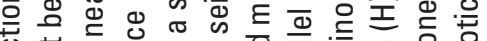

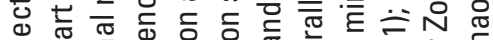

元 증

엉ㅎㅇ

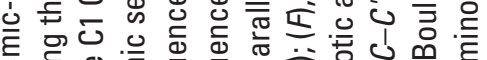

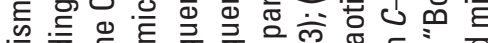

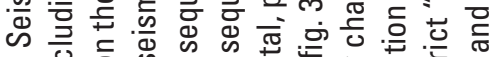

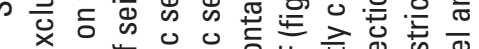

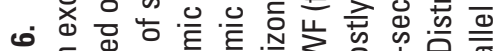

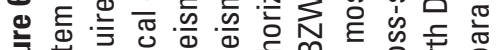

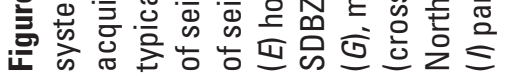




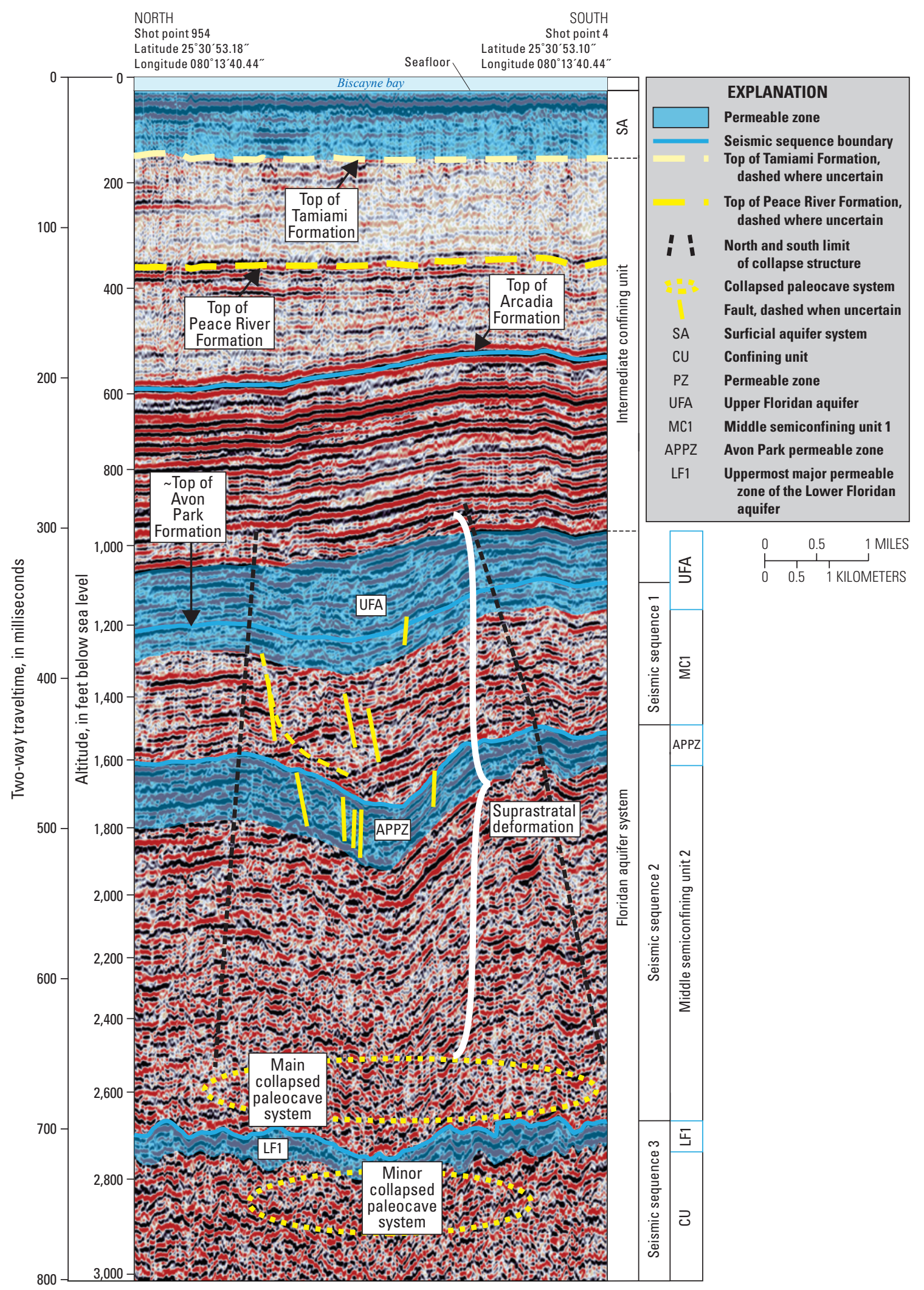

Figure 7. Seismic-reflection profile N5-pt3 from Biscayne Bay (fig. 1) showing a broad sag in seismic reflections interpreted as a collapse structure within the middle Eocene carbonate strata of the Floridan aquifer system. Onshore hydrostratigraphy is projected onto the profile. Modified from Cunningham and Walker (2009). 


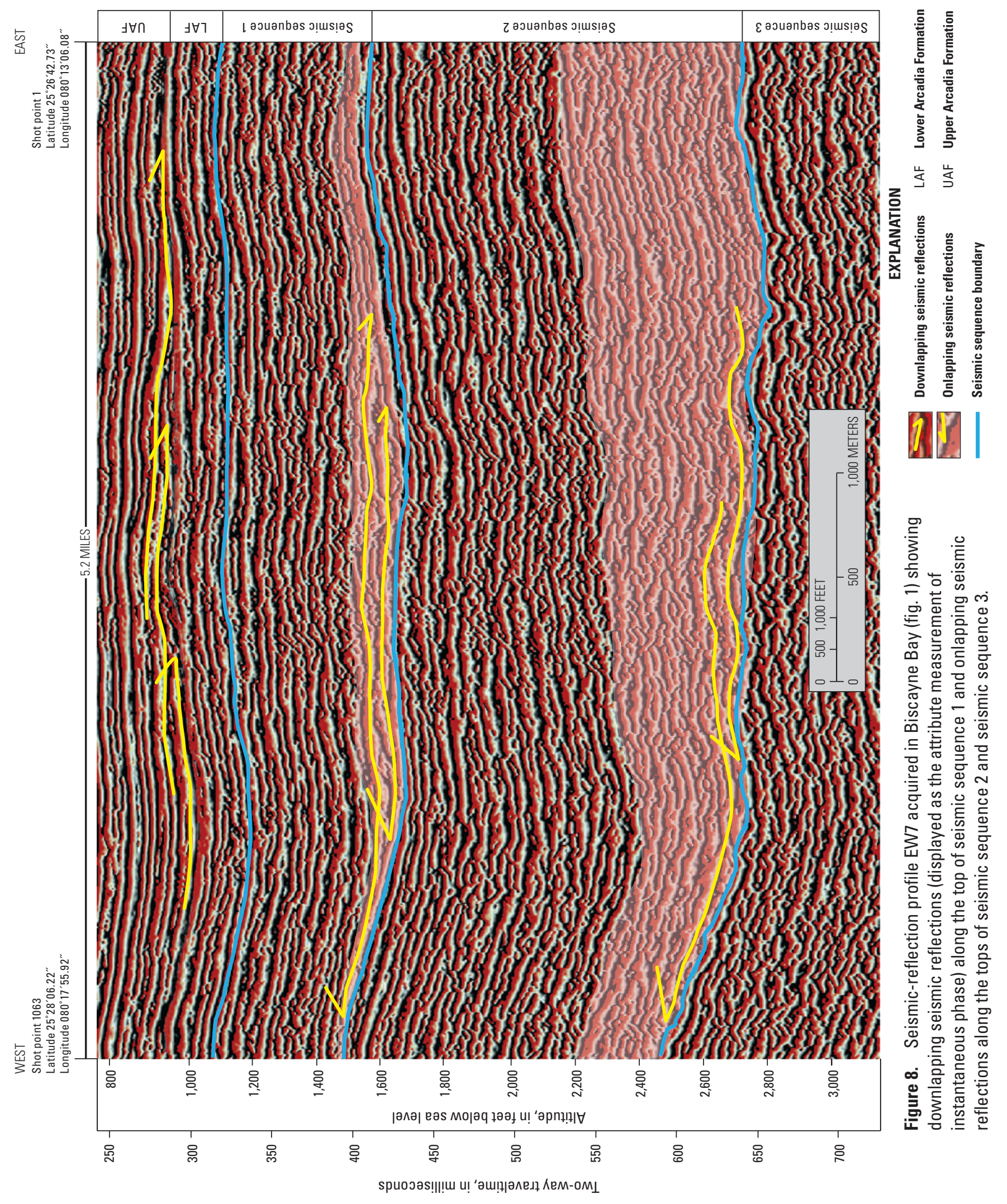


and beneath Biscayne Bay on seismic-reflection profile N5-pt3 (figs. 1 and 7) provide evidence for an extensive karst collapse structure (Cunningham and others, 2012). The structure has a roughly circular pattern when the outer diameter, determined from seismic-reflection profiles N5-p3, EW55, and EW6 (fig. 1), is projected onto a horizontal plane. The position of the karst collapse structure is above an interpreted major collapsed paleocave system in the lower part of seismic sequence 2 and a minor collapsed paleocave system in the upper part of seismic sequence 3 (fig. 7). A local, inverted V-shaped sag in seismic reflections that increases in width with depth on seismic-reflection profile 2TIE (fig. 9) indicates the presence of small karst collapse structures within seismic sequence 2 relative to the enormous collapse structure shown on figure 7. Onlapping seismic reflections of seismic sequence 1 onto the uppermost seismic reflection of seismic sequence 2 in the huge karst collapse structure in
Biscayne Bay (fig. 7) is evidence for an unconformity at the top of seismic sequence 2. The presence of both broad and narrow inverted $\mathrm{V}$-shaped seismic-refection configurations are indicative of karst collapse, faulting, and perhaps fracturing within the carbonate rocks of the Avon Park Formation that are assigned to seismic sequence 2 .

\section{Seismic Sequence 3}

The entire thickness of seismic sequence 3 is identified at the NDBZWF, SDBZWF, and on 2TIE (figs. $6 E-F$ ). Only the upper part of seismic sequence 3 is evident on water-based seismic-reflection data from SDBZWF (fig. $6 E$; cross-section $B-B^{\prime}$, pl. 1); however, the full thickness of seismic sequence 3 is delineated on the land-based seismicreflection data at SDBZWF (cross-section $C-C^{\prime}$, pl. 1).

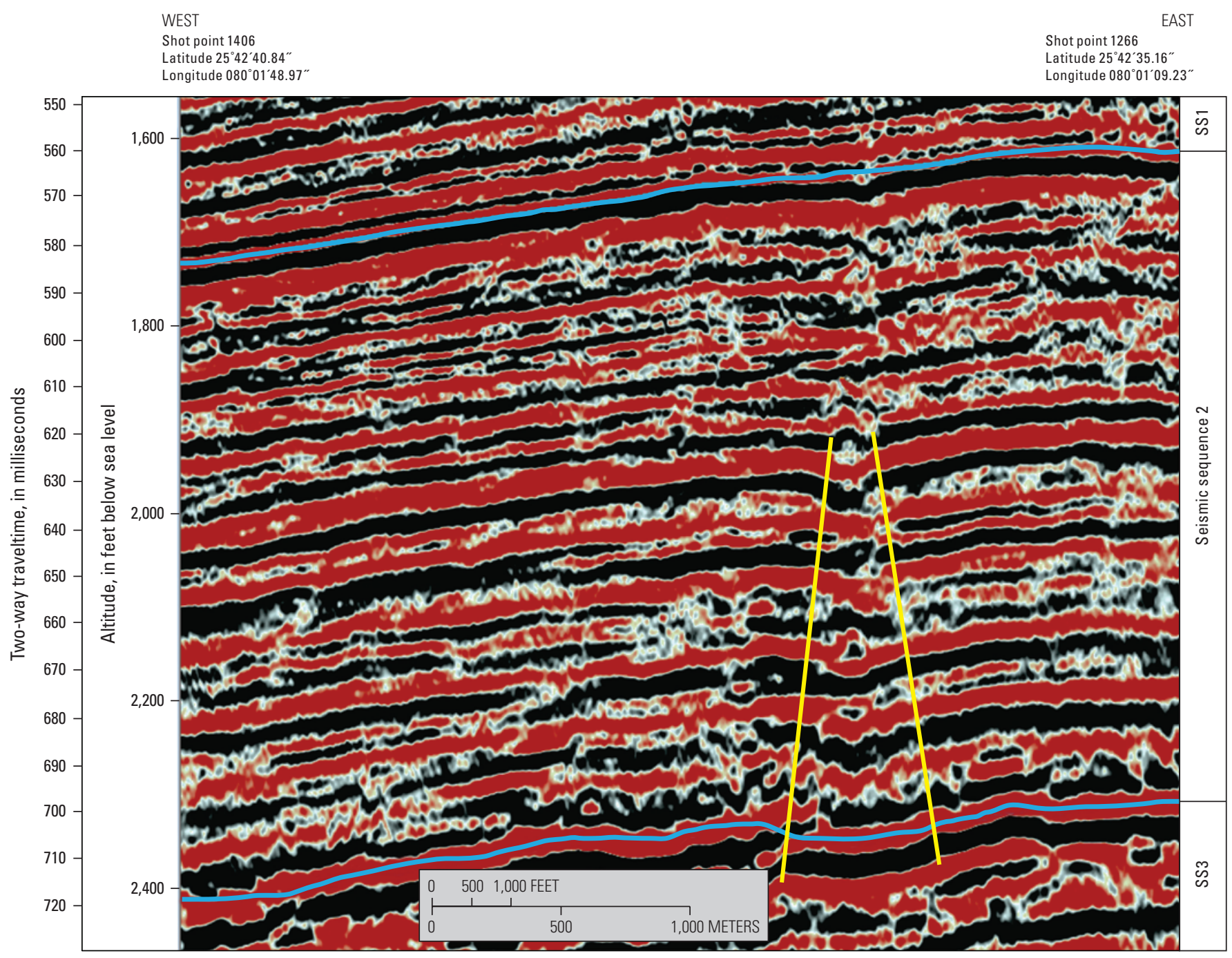

Figure 9. Part of seismic reflection profile 2TIE showing inverted V-shaped stacked seismic-reflection configurations within seismic sequence 2, indicative of a narrow karst collapse structure. The feature is centered at about shot point 1315 on line 2TIE (fig. 1).

EXPLANATION

Seismic sequence boundary Collapse structure boundaries SS1 Seismic sequence and number 
Seismic sequence 3 is characterized by continuous-todiscontinuous, subhorizontal, subparallel-to-wavy, hummocky or chaotic reflection configurations (fig. $6 E$ ). The strongest amplitudes and best reflection continuity are at or near the top of seismic sequence 3 (figs. $6 E-F$ ). Parallel seismic-reflection configurations with good continuity are common in seismic sequence 3 on seismic-reflection profile 2TIE (fig. $6 F$ ). At some locations within Biscayne Bay, seismic-reflection data display the basal reflections of seismic sequence 2 onlapping onto the upper seismic-reflection surface of seismic sequence 3 (fig. 9). The thickness of seismic sequence 3 ranges from roughly 120 to about $190 \mathrm{~ms}$ two-way traveltime. In one area on seismic-reflection profile 2TIE, broad, $\mathrm{U}$-shaped reflection configurations are present (fig. $6 F$ ). On seismic-reflection profile $\mathrm{C} 1$, three seismic-reflection sags are present along the uppermost seismic reflections of seismic sequence 3. Each sag shows offset in seismic reflections within the downward sagging reflections, indicating normal faulting (cross-section $B-B^{\prime}$, pl. 1).

Seismic sequence 3 is assigned to a part of the Floridan aquifer system located between the top of the uppermost major permeable zone of the Lower Floridan aquifer and the top of the Boulder Zone (fig. 4). Parallel seismic reflections with good continuity are common in seismic sequence 3 on seismic-reflection profile $2 \mathrm{TIE}$, probably indicating vertically stacked shallow-marine platform carbonates (Macurda, 1997). Broad, V-shaped reflection configurations on profile 2TIE are interpreted to represent faulted karst collapse structures in seismic sequence 3 (fig. 7). On the $\mathrm{C}-1$ seismic-reflection profile on the south side of the SDBZWF, seismic-reflection sags and observed reflection offsets may indicate karst collapse of the uppermost carbonate strata that the reflections represent and may indicate subaerial exposure and development of sinkholes along a major upper cycle boundary of the carbonate rocks that compose seismic sequence 3 (cross-section $B-B^{\prime}$, pl. 1). In addition, the onlapping of the base of seismic sequence 2 onto the upper reflection boundary of seismic sequence 3 may indicate a transgression during flooding of an exposure surface at the top of seismic sequence 3 (fig. 9).

\section{Seismic Sequence 4}

At the two study areas, the upper part of seismic sequence 4 is only delineated on the water-based seismicreflection data at NDBZWF and on the land-based seismic-reflection data at SDBZWF (figs. 1 and $6 G-H$; cross-sections $A-A^{\prime}$ and $C-C^{\prime}$, pl. 1). The only reliable representation of the entire thickness of seismic sequence 4 is on seismic-reflection profile 2TIE (fig. 6I). Seismic sequence 4 is not discernible on water-based seismic-reflection data at the SDBZWF, because chaotic reflection configurations dominate the lower part of these data at and below seismic sequence 4. Near the NDBZWF, seismic characteristics of seismic sequence 4 include discontinuous and subhorizontal, subparallel-to-wavy or hummocky reflection configurations with strongest amplitudes observed near the top of seismic sequence 4 (figs. $6 H$ ). On seismic-reflection profile 2TIE, seismic characteristics of seismic sequence 4 are subparallel or somewhat chaotic, wavy configurations (fig. 6l). Seismicreflection data from the NDBZWF and SDBZWF typically show seismic sequence 4 grading downward into chaotic configurations in the lower part, and the base of seismic sequence 4 is not definable. In one part of the NDBZWF study area, seismic-reflection data show seismic reflections at the base of seismic sequence 3 onlapping onto the top of seismic sequence 4 (fig. $6 H$ ).

The chaotic seismic-reflection configurations displayed within seismic sequence 4 on the profile 2TIE are probably indicative of karst collapse and fracturing between the upper and lower boundaries (fig. 61), similar to what has been reported for the Boulder Zone by Miller (1986). Dolomite dominates the lithology of the Boulder Zone (Miller, 1986), and it is more susceptible to brittle deformation than limestone having grainstone and packstone depositional textures that are common in the shallow-marine carbonate of the Oldsmar Formation and Avon Park Formation.

\section{Geologic Structure of the Floridan Aquifer System}

Cunningham and Walker (2009), Cunningham and others (2012), Cunningham (2013), and Reese and Cunningham $(2013$, 2014) described evidence of tectonic faults and karst collapse structures on seismic-reflection profiles acquired in southeastern Florida. These structures span Floridan aquifer system hydrogeologic units in southeastern Florida that were traditionally identified as confining, such as the upper part of the middle confining unit, which separates the Upper Floridan aquifer and Avon Park permeable zone. Within the Floridan aquifer system, these potential structural disruptions to vertical confinement have been identified only in rocks of lower Eocene to upper Oligocene age or possibly the lower Eocene to lower Miocene age (Cunningham and Walker, 2009; Cunningham and others, 2012; Cunningham, 2013; Reese and Cunningham, 2013). No faults were identified on seismic-reflection profiles acquired adjacent to the NDBZWF, however, a few were mapped on seismic-reflection profile $\mathrm{C}-1$ located south of the SDBZWF (cross-section $B-B^{\prime}$ on pl. 1). These faults extend downward from the upper bounding surface of seismic sequence 3 and the faults are likely related to three karst collapse structures in the upper part of seismic sequence 3. A strike-slip fault has been delineated using seismic-reflection profiles acquired in Biscayne Bay, however, which show the trend of the fault located as close as about $1.7 \mathrm{mi}$ east of the SDBZWF (fig. 10, pl. 1). Well data indicate the presence of a karst collapse within the Oldsmar Formation and lower part of the Avon Park Formation at NDBZWF (fig. 10, pl. 2); however, no karst collapse structures were identified on the seismic-reflection profiles acquired in the nearby C -9 Canal, Maule Lake, Oleta River, or the Intracoastal Waterway (fig. 2). 


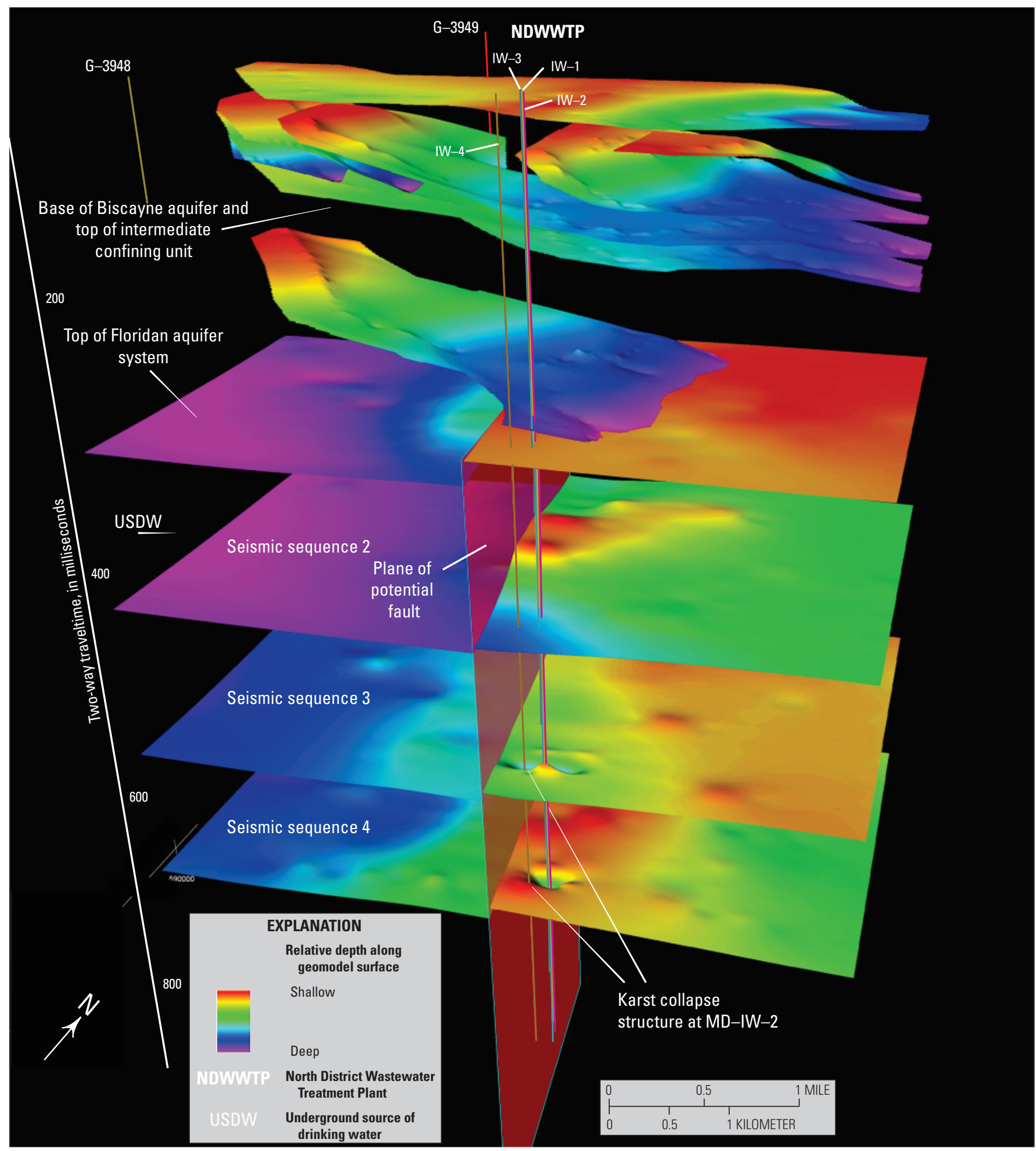

Figure 10. Three-dimensional diagram showing geomodel of the Miami-Dade North District "Boulder Zone" Well Field and surrounding area constructed from well-log data and seismic-reflection profiles (fig. 2). Two white leader lines point to the karst collapse structure penetrated by the MD-IW-2N well (pl. 2) and mapped as a circular-shaped depression at the top of seismic sequences 3-4. Test wells G-3949 and G-3948 provided information on the stratigraphic units composing the surficial aquifer (figs. 2). 


\section{Tectonic Faults}

Southeastern Florida seismic-reflection profiles reveal a strike-slip tectonic fault beneath Biscayne Bay and reverse tectonic faults beneath the Miami Terrace (fig. 1; Cunningham and others, 2012). On offshore seismic-reflection profiles, both the strike-slip fault and reverse faults are resolvable within seismic sequences $1-3$ of the Floridan aquifer system (figs. 11-13), but because of degrading data quality with increasing depth the faults are not observed in seismic sequence 4 . Although the hydraulic properties of the normal and reverse faults are unknown, these faults have the potential to act as pathways for the upward migration of buoyant effluent injected into the Boulder Zone if they are present onshore. Upward migration could extend into permeable zones and into the USDW in the upper part of the Floridan aquifer system, which includes the Upper Floridan aquifer and Avon Park permeable zone (fig. 4).

Five seismic-reflection profiles acquired in Biscayne Bay indicate that a strike-slip fault extends over a distance of at least $10 \mathrm{mi}$, approximately parallel to the shore

(figs. 1, 11, and 12, pl. 1). The fault is indicated on the profiles by vertical offset of reflections assigned to the upper part of the Avon Park Formation and upward to the top of the Arcadia Formation (figs. 11 and 12). The rocks that correlate to these seismic reflections are middle Eocene to middle Miocene age, assuming that the youngest age of the Arcadia Formation in southeastern Florida is middle Miocene (Guertin and others, 2000). Mapping of upper Miocene to upper Pliocene siliciclastics of the Peace River Formation of the Hawthorn Group (fig. 4) in southern Florida by Cunningham and others (2001a) indicates the fault offset at the top of the Arcadia Formation is downlapped by siliciclastics of late Miocene to early Pliocene age. Thus, fault movement occurred sometime within the middle Miocene to early Pliocene.

On each of the five seismic-reflection profiles, the strike-slip fault beneath Biscayne Bay shows a vertical offset in reflections of up to approximately $40 \mathrm{ft}$ or about $10 \mathrm{~ms}$ two-way traveltime (figs. 11 and 12). There is minor offset between reflections assigned to the Avon Park Formation and Arcadia Formation (figs. 11 and 12), with one exception at a seismic-sequence boundary that represents the top of the Arcadia Formation, where vertical offset can be up to about $30 \mathrm{~ms}$ two-way traveltime. The greater offset at the top of the Arcadia Formation indicates juxtaposition of displaced paleotopography on the upper surface of the Arcadia Formation (a prominent depositional sequence boundary) on opposite sides of the fault. Where observed, the paleotopography is higher on the eastern side of the fault compared to the western side. Additional evidence for strike-slip movement is based on a change in dip direction of the near-vertical fault plane, where the plane either displays westward or eastward dip on the five seismic-reflection profiles. The apparent dip of the fault observed on five seismic-reflection profiles ranges from $89^{\circ}$ west to $85^{\circ}$ east. The projected extension of the strike of this fault towards the northeast is through a data gap in seismic profiles about $19 \mathrm{mi}$ to the northeast and across an area about 0.4 mi west of the NDBZWF (fig. 1). Near the NDBZWF, a vertical offset of about 15 - to 20 -ms two-way traveltime is present in the seismic reflections assigned to the strata that compose the Floridan aquifer system within the gap between two seismic-reflection profiles (cross-section $A-A^{\prime}$, pl. 1). As with the strike-slip fault mapped beneath Biscayne Bay (fig. 1), the vertical displacement of seismic reflections indicates the seismic-sequence boundary at the top of the Arcadia Formation is higher on the east side relative to the west side of the presumed fault (cross-section $A-A^{\prime}$, pl. 1). Alternatively, a structural hinge line having a relatively steep dip toward the west may exist near the break in continuity of seismic-reflection profiles. Miller (1982) presented evidence for strike-slip faults in the panhandle of Florida. Klitgord and others (1984) and Thomas $(1988,2006)$ identified regional northwest-trending transform fault systems intersecting the Florida Platform that extend from the Bahamas into the northeastern Gulf of Mexico. The transform fault systems are related to the opening of the Atlantic Ocean (Klitgord and others, 1984; Thomas 1988, 2006). The strike-slip fault beneath Biscayne Bay is possibly related to movement along the regional transform fault systems.

Cunningham and others (2012) indicated that a group of reverse faults are present east of Miami-Dade County, beneath the Miami Terrace on the outer continental shelf in the Atlantic Ocean (figs. 1 and 12; Cunningham and others, 2012, fig. 1). Reverse-fault movement relates to the development of compressional anticlinal structures observed on the 2TIE profile (fig. 1), where seismic-reflections that probably represent late Pliocene- or early Pleistocene-age sediments downlap onto uplifted truncated seismic reflections assigned to the top of the lower Arcadia Formation (fig. 14). In addition, late Pliocene- or early Pleistocene-age sediments downlap onto and overstep horizontal wave-cut terraces, as indicated by seismic-reflections at the top of the Arcadia Formation (fig. 14). The horizontal buried terraces indicate that the compressional uplift ceased following erosion of the Oligocene or early Miocene lower Arcadia Formation and prior to deposition of the late Pliocene- or early Pleistocene-age sediments. The relations between these seismic-reflection geometries point to compressional uplift and reverse faulting sometime during the Oligocene to early Pleistocene. The timing of this uplift and reverse faulting in southeastern Florida postdates intense northerly-directed thrust movement in nearby Cuba during the early to middle Eocene (Pardo, 2009), and is more consistent with compressional stresses in the Cuban fold and thrust belt within the Bahamian foreland (Masaferro and others, 1999). Masaferro and others (1999) reported that movement at the frontal termination of the Cuban fold and thrust belt within the Bahamian foreland, about 150 mi southeast of Miami-Dade County, produced deformation under a compressional regime during the late Paleogene, Neogene, and probably during the Quaternary. These compressive stresses have been proposed to be a result of slow convergence between the North and South American plates (Masaferro and others, 1999). These regional stresses may have resulted in faulting and compressional 


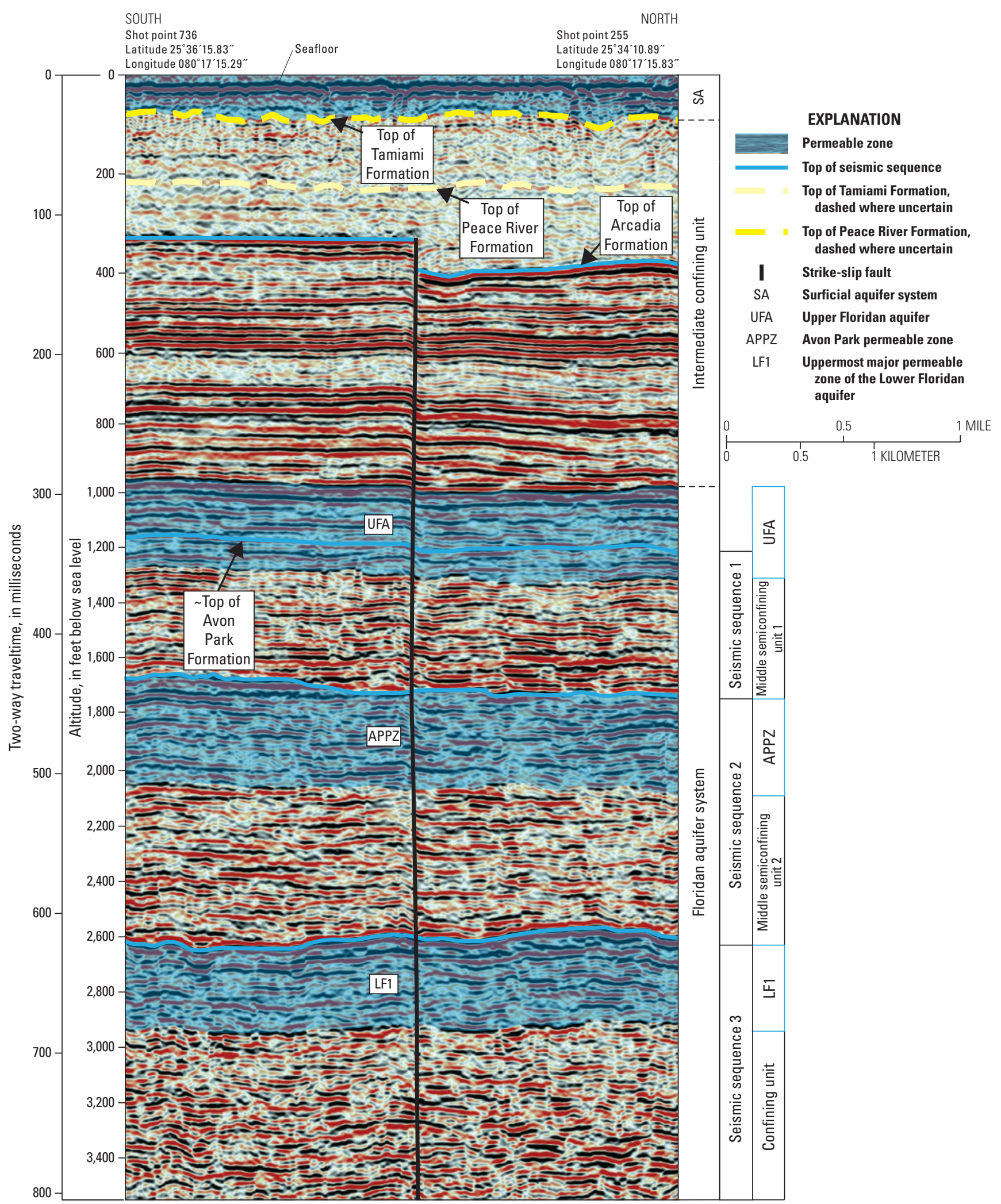

Figure 11. Seismic-reflection profile N1 from Biscayne Bay (fig. 1) showing a nearly vertical strike-slip fault. The structure is visible on five different seismic-reflection profiles (C2-HFE2, NECP, E2, N1, and C1; fig. 1) indicating its trace is about 10 miles or more in length. Onshore hydrostratigraphy is projected onto profile, although the upper and lower boundaries of the permeable units are located approximately. Onshore, the Upper Floridan aquifer and Avon Park permeable zone are protected underground sources of drinking water. Modified from Cunningham and others (2012). 


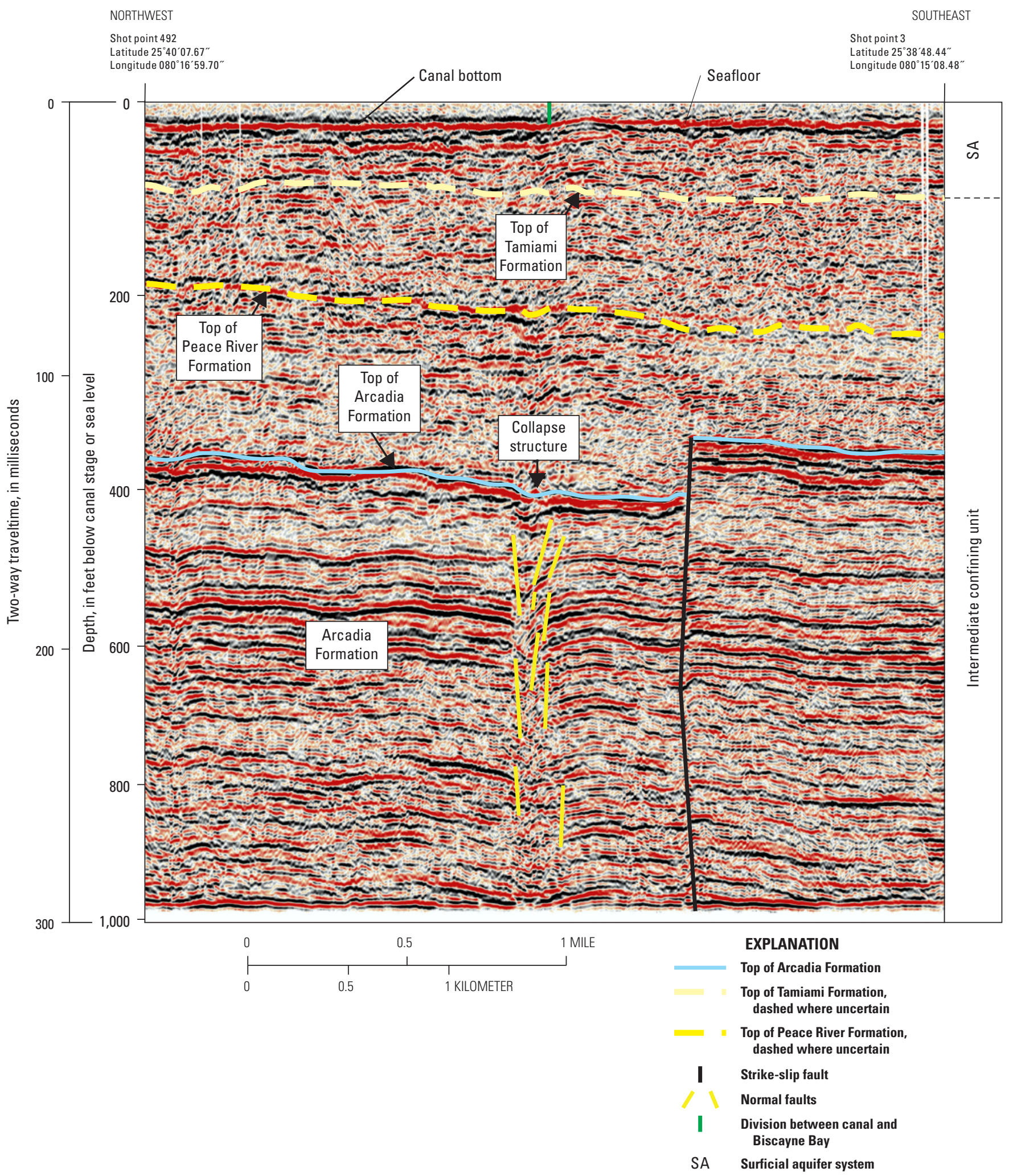

Figure 12. Seismic-reflection profile C2-HFE2 (fig. 1) showing a near-vertical strike-slip fault and a narrow karst collapse structure west of the fault. 


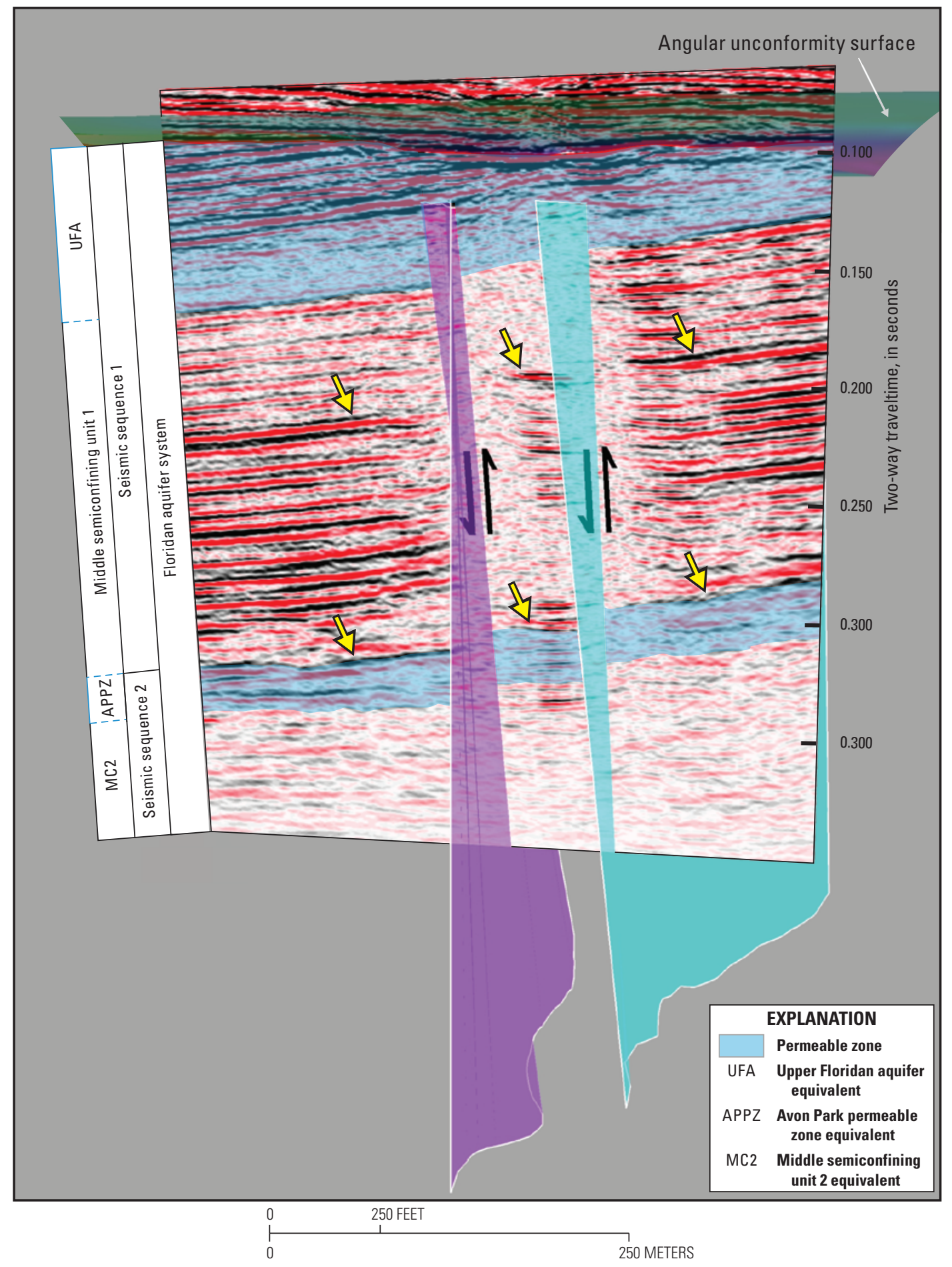

Figure 13. Three-dimensional diagram of geomodel based on 20 seismic-reflection profiles, including the 2TIE seismic-reflection profile (fig. 1; Cunningham and others, 2012). The geomodel shows a single seismic-reflection profile acquired from above the Miami Terrace (fig. 1) and two reverse fault planes (purple and cyan colored, arrows show relative movement) breaching reflections equivalent to middle Eocene carbonate strata of the Floridan aquifer system. Three fault planes are not shown in order to best show offset of the two principal reverse faults. Yellow arrows point to two seismic-reflections indicating structural offset between fault blocks. Reflections below the angular unconformity represent carbonate strata equivalent to an onshore upper part of the Florida aquifer system. Onshore, the Upper Floridan aquifer and Avon Park permeable zone are protected underground sources of drinking water. Modified from Cunningham and others (2012). 


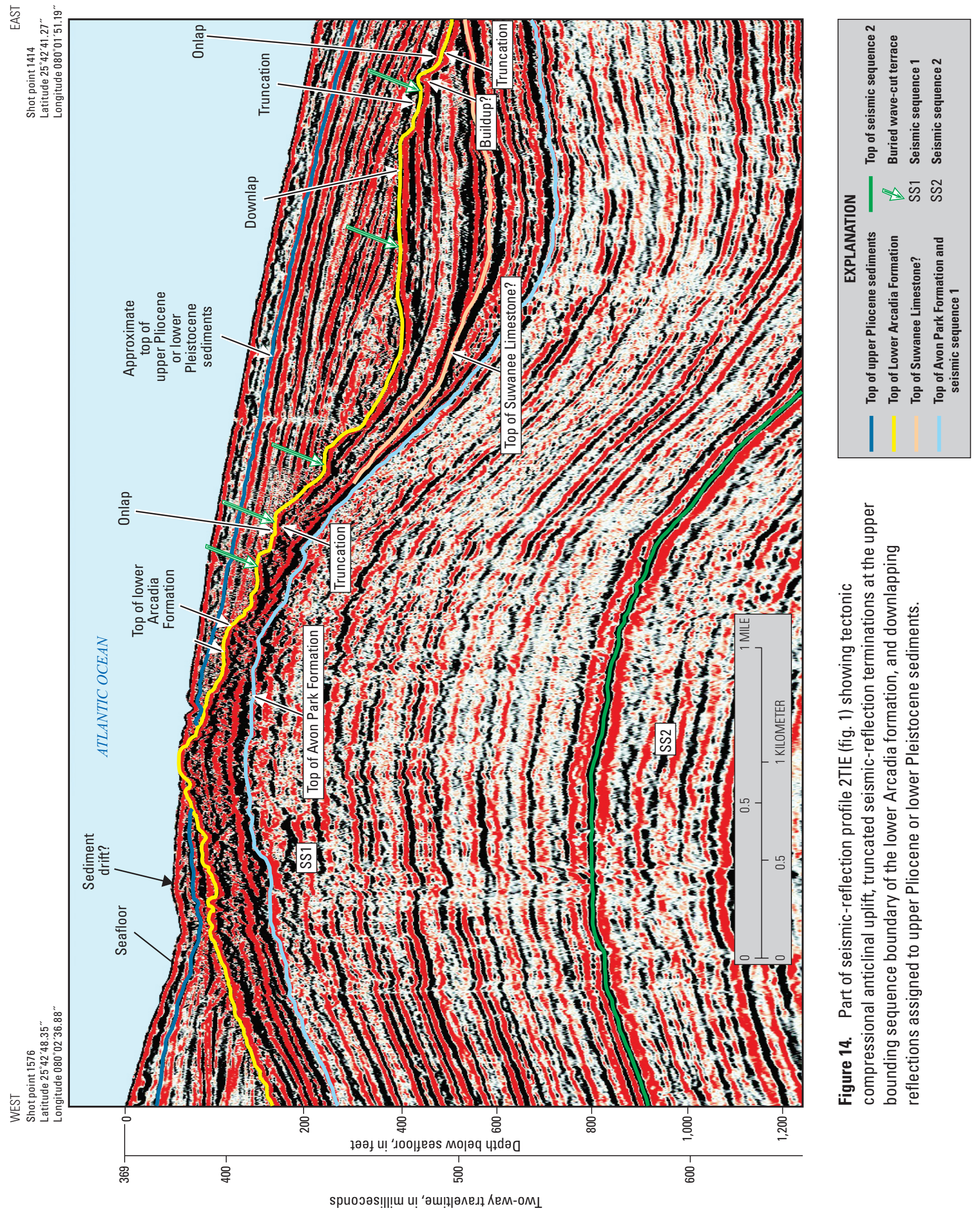


structures on the southeastern part of the Florida Platform. Reverse-fault movement sometime between the Oligocene to early Pleistocene is compatible with the timing of tectonic movement of the Santaren anticline (Southern Santaren Channel, Great Bahama Bank) reported by Masaferro and others $(1999,2002)$. To the east of the Florida Platform, Mulder and others (2013) reported observations that are consistent with late Cenozoic westward tectonic tilting on the Little Bahama Bank, which is temporally compatible with the uplift and reverse faulting shown in figure 13. The timing of the uplift and movement along these reverse faults is also consistent with the occurrence of a widespread compressional event in the late Miocene and early Pliocene that Missimer and Maliva (2004) proposed as the source of folding in southern Florida. This compressional event could have generated reverse faulting throughout southern Florida. Missimer and Maliva (2004) attribute tectonic deformation in southern Florida to episodic interactions between the Caribbean and North American plates southeast of the Florida Platform. Alternatively, it is possible that compressional uplift and reverse faulting imaged on seismic-reflection profile 2 TIE relates to movement along the Sunniland strike-slip fault system (Klitgord and others, 1984; McClay and Bonara, 2001). Finally, it is possible the timing of the movement along the reverse faults beneath the Miami Terrace coincides with middle Miocene to early Pliocene movement along the strike-slip fault mapped beneath Biscayne Bay.

\section{Buried Karst Collapse}

Cunningham and Walker (2009) identified numerous karst collapse structures in Biscayne Bay using marine seismic-reflection data acquired in 2007 and 2008. Additional karst collapse structures are evident in the seismic-reflection data acquired in 2010 from a canal in Broward County (Cunningham, 2013; Reese and Cunningham, 2013, 2014) and data collected in 2011 across the southeastern Florida continental shelf (for example, fig. $6 F$ ). This body of evidence supports the assertion that karst collapse structures are common structural features beneath southeastern peninsular Florida. The identified collapse structures range from about $400 \mathrm{ft}$ to approximately $3 \mathrm{mi}$ in diameter. The structures identified on seismic-reflection profiles exhibit concave-upward arrangements of mainly parallel seismic-reflection patterns. These patterns characterize physical features, as indicated by accompanying onlap, prograded-fill reflection configurations, erosional seismic-reflection terminations, or a mixture of these reflection patterns (Cunningham and Walker, 2009).

Although no karst collapse structures were observed on seismic-reflection profiles near the NDBZWF, hypogenic (Klimchouk, 2000) karst collapse and probable associated fault movement within a collapse structure in the carbonate Oldsmar Formation and lower part of the Avon Park Formation is evident above fractured, highly disturbed strata, and breccias that correspond to cave facies 3 and 4 of Loucks and others (pl. 2; 2004) as delineated from borehole videos acquired from the MD-IW-2N well (fig. 2, pl. 2). The cave facies are interpreted as vertically coalesced, collapsed paleocaves (pl. 2). Other evidence for karst collapse includes borehole geophysical log signatures (Ronald S. Reese, U.S. Geological Survey, written commun., 2009) that indicate highly fractured rock, and vertical offset of geophysical log markers at the MD-IW-2N well and in logs acquired from adjacent boreholes (pl. 2). High travel times measured on borehole sonic log data from about 2,000 $\mathrm{ft}$ bls to the top of the Boulder Zones are probably due to cycle skipping and indicate highly fractured rock composing the borehole wall in the MD-IW-2N, as does enlarged caliper measurements well beyond the drilled borehole diameter (Ronald S. Reese, U.S. Geological Survey, written commun., 2009; pl. 2). These borehole geophysical log data and borehole video data show that fractured and disturbed strata associated with the collapsed caves span a vertical interval of about $900 \mathrm{ft}$ from the top of the Boulder Zone to about $125 \mathrm{ft}$ above the top of the uppermost major permeable zone of the Lower Floridan aquifer (pl. 2). A much larger collapsed paleocave system, located in the lower part of seismic sequence 2 , has been mapped on seismic-reflection profiles beneath Biscayne Bay (fig. 7).

In other areas of Florida, investigators have documented karst collapse structures in carbonate rocks that have similar physical characteristics to the structures delineated in the Floridan aquifer system in southeastern Florida by Cunningham and Walker (2009), Cunningham and others (2012), Cunningham (2013), and Reese and Cunningham (2013, 2014). Karst collapse structures outside of southeastern Florida include examples located in (1) northeastern Florida (Kindinger and others, 2000; Spechler, 2001), (2) the La Belle area of the Caloosahatchee River (Cunningham and others, 2001b), (3) Tampa Bay and Charlotte Harbor in west-central Florida (Missimer and Gardner, 1976; Evans and Hine, 1991; Hine and others, 2009), (4) the northeast Florida shelf (Popenoe and others, 1984), and (5) the central Florida sinkhole district (Evans and others, 1994).

Examples of karst collapse structures outside Florida serve as comparative analogs that provide clues about the origin of karst collapse in southeastern Florida. Examples include the Lower Ordovician Ellenburger Group in western Texas (Loucks, 1999); Middle Ordovician dolomite and dolomitic limestone in southern China (Zou and others, 2009); Ordovician Ellenburger Group to Pennsylvanian carbonates of the Fort Worth Basin in Texas (Hardage and others, 1996; Sullivan and others, 2006; McDonnell and others, 2007); Cretaceous and Eocene carbonates offshore from Abu Dhabi, United Arab Emirates (El Awawdeh and others, 2008); and Miocene limestone in the South China Sea (Story and others, 2000; Heubeck and others, 2004). In addition, outcrop studies also serve as excellent analogs. For example, the study of Lucia (1995) focuses on cavern development, collapse, and dolomitization of the Lower Ordovician El Paso Group and Upper Ordovician Montoya Group in western Texas. Subsurface well data from the Ellenburger Group in western Texas (Kerans, 1988; Loucks, 1999; Loucks and others, 2004) are also useful analogs to collapse structures observed in the subsurface of southeastern Florida. 


\section{Summary and Conclusions}

This report presents a seismic-sequence stratigraphic and structural interpretation of seismic-reflection data acquired near the North and South District "Boulder Zone" Well Fields and guides the interpretation using analogs from nine seismicreflection profiles acquired during previous U.S. Geological Survey investigations in Biscayne Bay and across the Atlantic continental shelf. The goal of the study is to improve the understanding of the seismic structures and seismic-sequence stratigraphy of the rocks of the Floridan aquifer system and improve the ability to locate fluid-flow passageways in the Floridan aquifer system in southeastern Florida.

A principal result of the seismic-sequence stratigraphic analysis was the identification of four provisional seismic sequences, which extend from near the base of the of Floridan aquifer system to near the lower part of the intermediate confining unit. The upper seismic-sequence boundaries of three of these seismic sequences approximately correspond to the tops of the following major permeable units of the Floridan aquifer system: the Avon Park permeable zone, the uppermost major permeable zone of the Lower Floridan aquifer, and the Boulder Zone. The stratigraphic position of the top of the Floridan aquifer is variable in southeastern Florida, but is generally close to the upper boundary of the fourth or uppermost seismic sequence, which is equivalent to the upper surface of the Avon Park Formation. These relations between seismic-sequence stratigraphy and hydrostratigraphy allow for detailed mapping of the hydrostratigraphy of the Floridan aquifer system at a level of resolution never before achieved using well data alone. Notably, these results can be used to inform groundwater simulations designed to address the sustainability of the water resources of the Floridan aquifer system. The currently recognized seismic-sequence framework will probably be refined as the scope of seismic-sequence stratigraphic investigations by the U.S. Geological Survey and others in southeastern Florida expands.

Well data yielded another substantial finding, namely the identification of a karst collapse structure, which are common features beneath southeastern Florida, that extends upward about 900 feet from the top of the Boulder Zone to about 125 feet above the top of the uppermost major permeable zone of the Lower Floridan aquifer beneath the North District "Boulder Zone" Well Field. Boulder Zone injection well MD-IW-2N penetrates this karst collapse structure, as shown by borehole geophysical data acquired from the well. The karst collapse presumably is a vertical amalgamation of collapsed paleocaves. Although the karst collapse structure at the MD-IW-2N well has been identified using well data, no karst collapse structures were recognized on the seismicreflection profiles acquired nearby in the $\mathrm{C}-9$ Canal, Oleta River, Maule Lake, and the Intracoastal Waterway generally to the north and east of the North District "Boulder Zone" Well Field. However, karst collapse and associated faulting within the upper part of the lowermost major permeable zone of the Lower Floridan aquifer at the South District "Boulder Zone"
Well Field may be present at several locations based on seismic-reflection data acquired in the $\mathrm{C}-1 \mathrm{Canal}$. No faults were identified on seismic profiles at or directly adjacent to the North District "Boulder Zone" Well Field. However, a strikeslip fault imaged on five seismic-reflection profiles acquired in Biscayne Bay is about 1.7 miles to the east of South District "Boulder Zone" Well Field. Movement along this fault probably occurred sometime during the middle Miocene to early Pliocene. In addition, compressional anticlinal uplift and reverse faulting imaged beneath the Miami Terrace occurred sometime within the Oligocene to early Pleistocene. Perhaps the structural compression that produced the uplift and reverse faulting on the Atlantic continental shelf east of Miami and the strike-slip movement in Biscayne Bay relate to a region-wide tectonic event.

Recent studies by the U.S. Geological Survey of seismic-reflection profiles acquired in onshore canals and offshore in Biscayne Bay and the Atlantic continental shelf have indicated the presence of tectonic faults (one strike-slip fault and multiple reverse faults) and karst collapse structures, and these studies substantiate the utility of this approach for locating feasible vertical-fluid flow pathways. The strike-slip fault and karst collapse structures span confining units of the Floridan aquifer system and could provide high permeability passageways for groundwater movement. If present at or near wastewater injection utilities, these features represent a plausible physical system for the upward migration of effluent injected into the Boulder Zone to overlying U.S. Environmental Protection Agency designated underground sources of drinking water in the upper part of the Floridan aquifer system.

\section{References Cited}

Applin, P.L., and Applin, E.R., 1944, Regional subsurface stratigraphy and structure of Florida and southern Georgia: American Association of Petroleum Geologists Bulletin, v. 28 , p. $1673-1753$.

Brewster-Wingard, G.L., Scott, T.M., Edwards, L.E., Weedman, S.D., and Simmons, K.R., 1997, Reinterpretation of the peninsular Florida Oligocene-An integrated stratigraphic approach: Sedimentary Geology, v. 108, p. 207-228.

Bruns, T.R., Geist, E.L., and Lavoie, D.L., 1994, Chapter 21Synthetic seismograms, migrated seismic reflection profiles, and lithologic correlations for Leg 135 sites in the Lau Basin and Tonga Arc, in Hawkins, J.W., Parson, L.M., Allan, J.F., and others, eds., Proceedings of the Ocean Drilling Program, Scientific Results, Lau Basin; Covering Leg 135 of the Cruises of the Drilling Vessel JOIDES Resolution, Suva Harbor, Fiji, to Honolulu, Hawaii, Sites 834-841, 17 December 1990-28 February 1991: Texas A\&M University, Ocean Drilling Program, College Station, Texas, v. 135, p. 331-365. 
Budd, D.A., Saller, A.H., and Harris, P.M., eds., 1995, Unconformities and porosity in carbonate strata: Tulsa, Okla., American Association of Petroleum Geologists Memoir 63, $313 \mathrm{p}$.

Cartwright, J., Huuse, M., and Aplin, A., 2007, Seal bypass systems: American Association of Petroleum Geologists Bulletin, v. 91, p. 1141-1166.

CH2MHILL, 2013, Construction and testing of Class I injection well IW-1 and monitoring well MW-1 for the Biscayne Landing groundwater remediation system: Report prepared for City of North Miami, 6 sections, [about 672] p.

Cooke, C.W., and Mansfield, W.C., 1936, Suwannee Limestone of Florida: Geological Society of America Proceedings, p. 71-72.

Cunningham, K.J., 2013, Integrating seismic-reflection and sequence-stratigraphic methods to characterize the hydrogeology of the Floridan aquifer system in southeast Florida: U.S. Geological Survey Open-File Report 2013-1181, 8 p.

Cunningham, K.J., Bukry, D., Sato, T., Barron, J.A., Guertin, L.A., and Reese, R.S., 2001a, Lithostratigraphy, sequence stratigraphy and biostratigraphy of a carbonate ramp and bounding siliciclastics (Late Miocene-Pliocene), southern Florida: Florida Geological Survey Special Publication 49, p. 35-66.

Cunningham, K.J., Locker, S.D., Hine, A.C., Bukry, David, and Barron, J.A., 2001b, Surface-geophysical characterization of ground-water systems of the Caloosahatchee River Basin, southern Florida: U.S. Geological Survey WaterResources Investigations Report 01-4084, 76 p.

Cunningham, K.J., Locker, S.D., Hine, A.C., Bukry, David, Barron, J.A., and Guertin, L.A., 2003, Interplay of Late Cenozoic siliciclastic supply and carbonate response on the southeast Florida Platform: Journal of Sedimentary Research, v. 73, p. 31-46.

Cunningham, K.J., McNeill, D.F., Guertin, L.A., Ciesielski, P.F., Scott, T.M., and de Verteuil, Laurent, 1998, New Tertiary stratigraphy for the Florida Keys and southern peninsula of Florida: Geological Society of America Bulletin, v. 110 , p. $231-258$

Cunningham, K.J., and Walker, C., 2009, Seismic-sag structures in Tertiary carbonate rocks beneath southeastern Florida, USA —Evidence for hypogenic speleogenesis?, in Klimchouk, A.B., and Ford, D.C., eds., Hypogene Speleogenesis and Karst Hydrogeology of Artesian Basins: Simferopol, Ukraine, Ukrainian Institute of Speleology and Karstology, Special Paper no. 1, p. 151-158, accessed October 3, 2014, at http://institute.speleoukraine.net/ libpdf/Cunningham $\% 20$ Walker_SEISMIC-SAG\%20 STRUCTURAL\%20SYSTEMS\%20IN\%20FLORIDA_ HypoConf_2009.pdf.
Cunningham, K.J., Walker, C., and Westcott, R.L., 2012, Near-surface, marine seismic-reflection data define potential hydrogeologic confinement bypass in the carbonate Floridan aquifer system, southeastern Florida: Society of Exploration Geophysicists Annual Meeting, Las Vegas, NV, 6 p., accessed October 3, 2014 at http://library.seg.org/doi/ abs/10.1190/segam2012-0638.1.

Dallmeyer, R.D., 1989, Contrasting accreted terranes in the southern Appalachian orogen and Atlantic-Gulf coastal plains and their correlations with West African sequences, in Dallmeyer, R.D., ed., Terranes in the circum-Atlantic Paleozoic orogens: Geological Society of America Special Paper 230, p. 247-268.

Dausman, A.M., Doherty, J., Langevin, C.D., and Dixon, J., 2010, Hypothesis testing of buoyant plume migration using a highly parameterized variable-density groundwater model at a site in Florida, USA: Hydrogeology Journal, v. 18, p. 147-160.

Duncan, J.G., Evans, W.L., III, Aylor, J.G., and Li, Li, 1994, Geologic framework of the Lower Floridan aquifer system, St. Lucie, Martin and Palm Beach Counties, Florida: Tallahassee, Florida Geological Survey, Contractual report submitted to the Florida Department of Environmental Protection Bureau of Drinking and Ground Water Resources UIC, Criteria and Standards DEP Contract \#WM514.

El Awawdeh, R., Khouri, N., Al Neyadi, A., Shevchek, Z.J., Shebl, H., and Edwards, H.E., 2008, 3-D seismic evidence of Tertiary-Cretaceous karsts \& collapse disturbances from offshore oil field in Abu Dhabi and outcrop analogs from Jebel Hafit, United Arab Emirates: Society of Petroleum Engineers, SPE 118006, 13 p.

Enos, P., and Perkins, R.D., 1977, Quaternary sedimentation of South Florida: Geological Society of America Memoir 147, $198 \mathrm{p}$.

Evans, M.W., and Hine, A.C., 1991, Late Neogene sequence stratigraphy of a carbonate-siliciclastic transition-Southwest Florida: Geological Society of America Bulletin: v. 103, p. 679-699.

Evans, M.W., Snyder, S.W., and Hine, A.C., 1994, Highresolution seismic expression of karst evolution within the upper Floridan aquifer system - Crooked Lake, Polk County, Florida: Journal of Sedimentary Research, v. B64, no. 2, p. 232-244.

Guertin, L.A., Missimer, T.M., and McNeill, D.F., 2000, Hiatal duration of correlative sequence boundaries from OligocenePliocene mixed carbonate/siliciclastic sediments of the south Florida Platform: Sedimentary Geology, v. 134, p. 1-26.

Hardage, B.A., Carr, D.L., Lancaster, D.E., Simmons, J.L., Jr., Elphick, R.Y., Pendleton, V.M., and Johns, R.A., 1996, 3-D seismic evidence of the effects of carbonate karst collapse on overlying clastic stratigraphy and reservoir compartmentalization: Geophysics, v. 61, p. 1336-1350. 
Heggland, R., 1997, Detection of gas migration from a deep source by the use of exploration 3D seismic data: Marine Geology, v. 137, p. 41-47.

Heubeck, C., Story, K., Peng, P., Sullivan, C., and Duff, S., 2004, An integrated reservoir study of the Liuhua 11-1 field using a high-resolution three-dimensional seismic data set, in Eberli, G.P., Masaferro, J.L., and Sarg, J.F., eds., Seismic imaging of carbonate reservoirs and systems: American Association of Petroleum Geologists Memoir 81, p. 149-168.

Hine, A.C., 2009, Geology of Florida: Independence, Kentucky, Brooks/Cole, 30 p.

Hine, A.C., 2013, Geologic history of Florida-Major events that formed the sunshine state: Gainesville, Florida, University of Florida Press, 230 p.

Hine, A.C., Suthard, B., Locker, S.D., Cunningham, K.J., Duncan, D.S., Evans, M., and Morton, R.A., 2009, Karst subbasins and their relationship to the transport of Tertiary siliciclastic sediments on the Florida Platform, in Swart, P.K., Eberli, G.P., and McKenzie, J., eds., Perspectives in sedimentary geology - A tribute to the career of Robert N. Ginsburg: Oxford, Wiley-Blackwell, International Association of Sedimentologists Special Publication, v. 41, p. 179-197.

Horton, J.W., Drake, A.A., Jr., Rankin, D.W., and Dallmeyer, R.D., 1991, Preliminary tectonostratigraphic terrane map of the central and southern Appalachians: U.S. Geological Survey Miscellaneous Investigations Series Map I-2163, scale 1:2,000,000, 1 sheet.

James, N.P., 1997, The cool-water carbonate depositional realm, in James, N.P., and Clarke, J.A.D., eds., Cool-water carbonates: Society for Sedimentary Geology Special Publication 56, p. 1-20.

Kerans, C., 1988, Karst-controlled reservoir heterogeneity in Ellenburger Group carbonates of west Texas: American Association of Petroleum Geologists Bulletin, v. 72, p. $1160-1183$.

Kindinger, J.L., Davis, J.B., and Flocks, J.G., 2000, Subsurface characterization of selected water bodies in the St. Johns River Water Management District, northeast Florida: U.S. Geological Survey Open-File Report 00-180, 46 p.

Klimchouk, Alexander, 2000, Speleogenesis under deep-seated and confined settings, in Klimchouk, A.B., Ford, D.C., Palmer, A.N., and Dreybodt, Wolfgang, eds., Speleogenesis evolution of karst aquifers: National Speleological Society, Inc., Huntsville, AL, p. 244-260.

Klitgord, K.D., Popenoe, P., and Schouten, H., 1984, Florida-A Jurassic transform plate boundary: Journal of Geophysical Research, v. 89, no. B9, p. 7753-7772.
Ligtenberg, J.H., 2005, Detection of fluid migration pathways in seismic data-Implications for fault seal analysis: Basin Research, v. 17, p. 141-154.

Loucks, R.G., 1999, Paleocave carbonate reservoirs-Origins, burial-depth modifications, spatial complexity, and reservoir implications: American Association of Petroleum Geologists Bulletin, v. 83, p. 1795-1834.

Loucks, R.G., Mecher, P.K., and McMechan, G.A., 2004, Three-dimensional architecture of a coalesced, collapsed paleocave system in the Lower Ordovician Ellenburger Group, central Texas: American Association of Petroleum Geologists Bulletin, v. 88, p. 545-564.

Lucia, F.J., 1995, Lower Paleozoic cavern development, collapse, and dolomitization, Franklin Mountains, El Paso, Texas, in Budd, D.A., Saller, A.H., and Harris, P.M., eds., Unconformities and porosity in carbonate strata: American Association of Petroleum Geologists Memoir 63, p. 279-300.

Macurda, D.B., Jr., 1997, Carbonate seismic facies analyses, in Palaz, Ibrahim, and Marfurt, K.J., eds., Carbonate seismology: Society of Exploration Geophysicists, Geophysical Developments Series, no. 6, p. 95-119.

Maliva, R.G., Guo, W., and Missimer, T., 2007, Vertical migration of municipal wastewater in deep injection well systems, South Florida, USA: Hydrogeology Journal, v. 15, p. 1387-1396.

Masaferro, J.L., Bulnes, M., Poblet, J., and Eberli, G.P., 2002, Episodic fold uplift inferred from the geometry of syntectonic carbonate sedimentation-The Santaren anticline, Bahamas foreland: Sedimentary Geology, v. 146, p. 11-24.

Masaferro, J.L., Poblet, J., Bulnes, M., Eberli, G.P., Dixon, T.H., and McClay, K., 1999, Palaeogene-Neogene/present day(?) growth folding in the Bahamian foreland of the Cuban fold and thrust belt: Journal of the Geological Society of London, v. 156, p. 617-631.

McClay, K., and Bonora, M., 2001, Analog models of restraining stepovers in strike-slip fault systems: American Association of Petroleum Geologists, v. 85, p. 233-260.

McDonnell, A., Loucks, R.G., and Dooley, T., 2007, Quantifying the origin and geometry of circular sag structures in northern Fort Worth Basin, Texas-Paleocave collapse, pull-apart fault systems, or hydrothermal alteration?: American Association of Petroleum Geologists Bulletin, v. 91, 1295-1318.

Miami-Dade Water and Sewer Department, 1996, Construction, drilling and testing of 7 Upper Floridan monitor wells FA-10 through FA-16: Contract no. S-508, 6 sections, [about 860] p. 
Miami-Dade Water and Sewer Department, 2002, Drilling and testing of injection well IW-3N and monitoring well FA-3N at North District "Boulder Zone" Well Field: Contract no. S-604, 6 sections, [about 497] p.

Miller, J.A., 1982, Structural control of Jurassic sedimentation in Alabama and Florida: American Association of Petroleum Geologists Bulletin, v. 66, p. 1289-1301.

Miller, J.A., 1986, Hydrogeologic framework of the Floridan aquifer system in Florida and in parts of Georgia, Alabama, and South Carolina: U.S. Geological Survey Professional Paper 1403-B, 91 p., 33 pls.

Miller, J.A., 1990, Ground water atlas of the United StatesSegment 6, Alabama, Florida, Georgia, and South Carolina: U.S. Geological Survey Hydrologic Investigation Atlas 730-G, $28 \mathrm{p}$.

Missimer, T.M., and Gardner, R.A., 1976, High-resolution seismic reflection profiling for mapping shallow aquifers in Lee County, Florida: U.S. Geological Survey WaterResources Investigations Report 76-45, 30 p.

Missimer, T.M., and Maliva, R.G., 2004, Tectonically induced fracturing, folding, and groundwater flow in South Florida: Gulf Coast Association of Geological Societies Transactions, v. 54, p. 443-459.

Mitchell-Tapping, H.J., Bellucci, J.R., Woody, G., and Lee, T.J., 1999, Mud Hole-A unique warm-water spring, located offshore southwestern Florida: Gulf Coast Association of Geological Societies Transactions, v. 49, p. 370-383.

Mitchum, R.M., Jr., Vail, P.R., and Thompson, S., III, 1977, Seismic stratigraphy and global changes of sea level, Part 6-Stratigraphic interpretation of seismic reflection patterns in depositional sequences: in Payton, C.E., ed., Seismic stratigraphy-Applications to hydrocarbon exploration: American Association of Petroleum Geologists Memoir 26, p. 117-133.

Mulder, T., Ducassou, E., Gillet, H., and others, 2013, Canyon morphology on a modern carbonate slope of the Bahamas-Evidence of regional tectonic tilting: Geology, v. 40, p. 771-774.

Pardo, G., 2009, Geology of Cuba: Tulsa, Oklahoma, American Association of Petroleum Geologists Studies in Geology 58, 73 p.

Parker, G.G., and Cooke, C.W., 1944, Late Cenozoic geology of southern Florida, with a discussion of the ground water: Florida Geological Survey Bulletin 27, 119 p.

Poag, W.C., 1991, Rise and demise of the Bahama-Grand Banks Gigaplatform, northern margin of the Jurassic ProtoAtlantic Seaway: Marine Geology, v. 102, p. 63-130.
Pomar, L., 2001, Types of carbonate platforms-A genetic approach: Basin Research, v. 13, p. 313-334.

Popenoe, P., Kohout, F.A., and Manheim, F.T., 1984, Seismicreflection studies of sinkholes and limestone dissolution features on the northeastern Florida shelf, in B.F. Beck, ed., Sinkholes-Their geology, engineering, and environmental impact: Proceedings of First Multidiscipline Conference on Sinkholes, 43-57.

Puri, H.S., and Winston, G.O., 1974, Geologic framework of high transmissivity zones in south Florida: Florida Bureau of Geology Special Publication 20, $101 \mathrm{p}$.

Reese, R.S., 1994, Hydrogeology and the distribution and origin of salinity in the Floridan aquifer system, southeastern Florida: U.S. Geological Survey Water-Resources Investigations Report 94-4010, 56 p.

Reese, R.S., and Cunningham, K.J., 2013, Preliminary stratigraphic and hydrogeologic cross sections and seismic profile of the Floridan aquifer system of Broward County, Florida: U.S. Geological Survey Open-File Report 20131141, 10 p., accessed October 3, 2014, at http://pubs.usgs. gov/of/2013/1141.

Reese, R.S., and Cunningham, K.J., 2014, Hydrogeologic framework and salinity distribution of the Floridan aquifer system of Broward County, Florida: U.S. Geological Survey Scientific Investigations Report 2014-5029, 60 p, accessed April 8, 2014, at http://pubs.usgs.gov/sir/2014/5029/.

Reese, R.S., and Richardson, E., 2008, Synthesis of the hydrogeologic framework of the Floridan aquifer system and delineation of a major Avon Park permeable zone in central and southern Florida: U.S. Geological Survey Scientific Investigations Report 2007-5207, 60 p., 4 pls., plus apps. (on $\mathrm{CD}$ ).

Roberts-Ashby, T., Stewart, M.T., and Ashby, B.N., 2013, An evaluation of porosity and potential use for carbon dioxide storage in the Upper Cretaceous Lawson Formation and Paleocene Cedar Keys Formation of south-central and southern Florida: Environmental Geosciences, v. 20, p. 109-135.

Ross, M.I., and Scotese, C.R., 1988, A hierarchical tectonic model of the Gulf of Mexico and Caribbean region: Tectonophysics, v. 155, p. 139-168.

Schlager, W., 1989, Drowning unconformities on carbonate platforms, in Crevello, P.D., Wilson, J.L., Sarg, J.F., and Read, J.F., eds., Controls on carbonate platform and basin development: Society of Economic Paleontologists and Mineralogists Special Publication 44, p. 15-25.

Schlager, W., 1999, Type 3 sequence boundary, in Harris, P.M., Saller, A.H., and Simo, J.A., eds., Advances in carbonate sequence stratigraphy: application to reservoirs, outcrops and models: Society of Economic Paleontologists and Mineralogists Special Publication 63, p. 35-45. 
Scott, T.M., 1988, The lithostratigraphy of the Hawthorn Group (Miocene) of Florida: Florida Geological Survey Bulletin 59, $148 \mathrm{p}$.

Smith, D.L., and Lord, K.M., 1997, Tectonic evolution and geophysics of the Florida basement, in Randazzo, A.F., and Jones, D.S., eds., The geology of Florida: Gainesville, Florida, University Press of Florida, p. 13-26.

Spechler, R.M., 2001, The relation between structure and saltwater in the Floridan aquifer system, northeastern Florida, in U.S. Geological Survey Karst Interest Group Proceedings: U.S. Geological Survey Water-Resources Investigations Report 01-4011, p. 25-29.

Sproul, C.R, Boggess, D.H., and Woodward, H.J., 1972, Saline water intrusion from deep artesian sources in the McGregor Isles area of Lee County, Florida: Florida Bureau of Geology Information Circular 75, $30 \mathrm{p}$.

Story, C., Peng, P., Heubeck, C., Sullivan, C., and Dong Lin, J., 2000, Liuhua 11-1 Field, South China Sea-A shallow carbonate reservoir developed using ultrahigh-resolution 3-D seismic, inversion, and attribute-based reservoir modeling: The Leading Edge, v. 19, no. 8, p. 834-844.

Sullivan, E.C., Marfurt, K.J., Lacazette, A., and Ammerman, M., 2006, Application of new seismic attributes to collapse chimneys in the Fort Worth Basin: Geophysics, v. 71, no. 4, p. B111-B119.

Thomas, W.A., 1988, Early Mesozoic faults of the northern Gulf Coastal Plain in the context of opening of the Atlantic Ocean, in Maspeizer, W., ed., Triassic-Jurassic rifting: Amsterdam, Elsevier, p. 461-476.

Thomas, W.A., 2006, Tectonic inheritance at a continental margin: GSA Today, v. 16, p. 4-11.

U.S. Environmental Protection Agency, 2013, Water: Underground Injection Control-Glossary: U.S. Environmental Protection Control Web page, accessed October 3, 2014, at http://water.epa.gov/type/groundwater/uic/glossary.cfm\#t.

Walsh, V., and Price, R.M., 2010, Determination of vertical and horizontal pathways of injected fresh wastewater into a deep saline aquifer (Florida, USA) using natural chemical tracers: Hydrogeology Journal, v. 18, p. 1027-1042.

Warzeski, E.R., Cunningham, K.J., Ginsburg, R.N., Anderson, J.B., and Ding, Z.-D., 1996, A Neogene mixed siliciclastic and carbonate foundation for the Quaternary carbonate shelf, Florida Keys: Journal of Sedimentary Research, v. 66, p. $788-800$.

Zuo, J.-P., Peng, S.-P., Li, Y.-J., Chen, Z.-H., and Xie, H.P., 2009, Investigation of karst collapse based on 3-D seismic technique and DDA method at Xieqiao coal mine, China: International Journal of Coal Geology, v. 78, p. 276-287. 
Manuscript approved January 27, 2015

Prepared by the Raleigh Publishing Service Center Michael Deacon, Editor

Kimberly Swidarski, Illustrations and layout

For more information about this publication, contact:

Director

U.S. Geological Survey

Caribbean-Florida Water Science Center

4446 Pet Lane, Suite 108

Lutz, FL 33559

(813) 498-5000

or visit our Web site at http://fl.water.usgs.gov 
